Prepared in cooperation with the City of De Soto, Missouri

\title{
Two-Dimensional Hydraulic Analyses of Joachim Creek, De Soto, Missouri
}

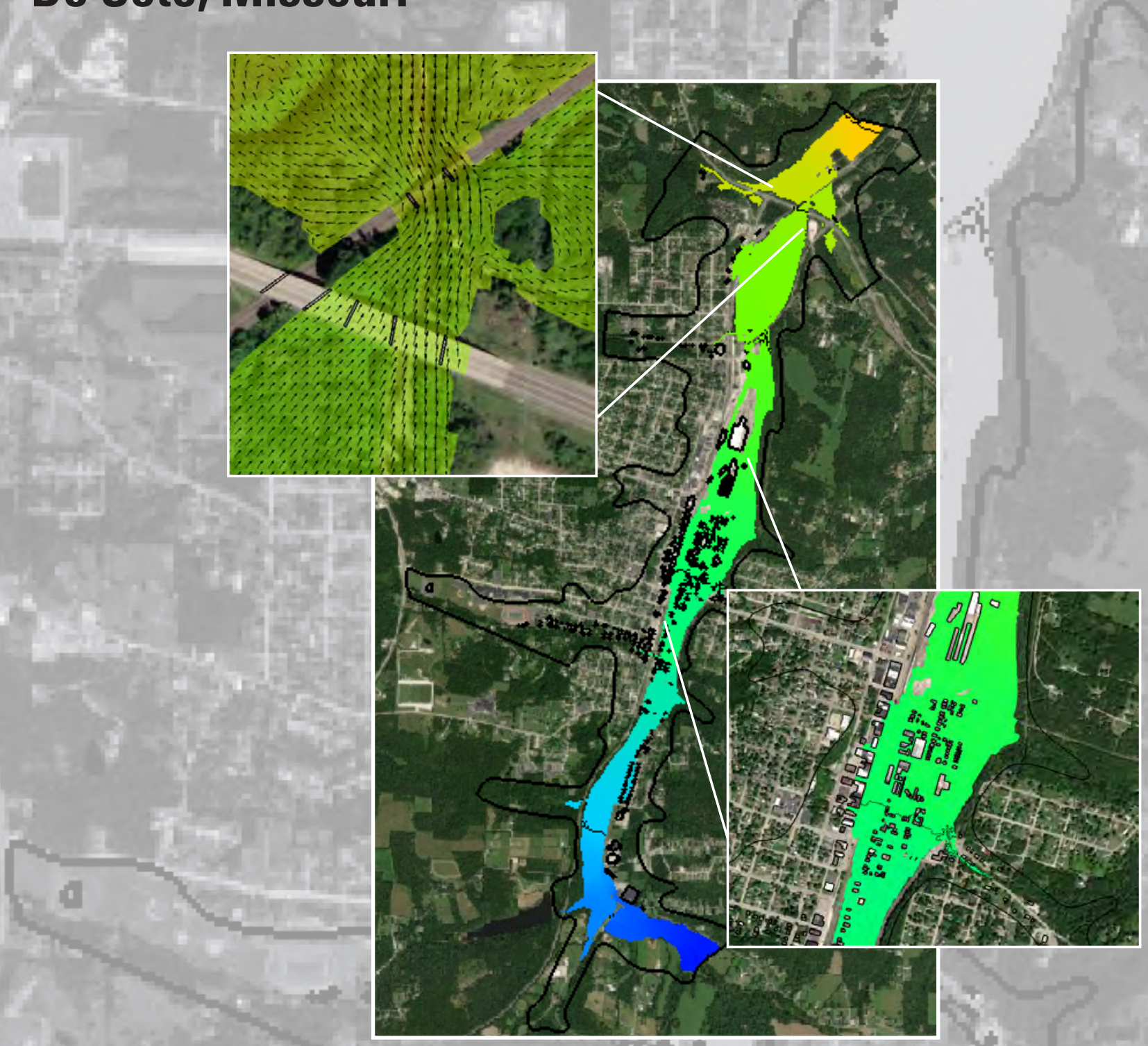

Scientific Investigations Report 2021-5058

U.S. Department of the Interior

U.S. Geological Survey 
Cover. Images of the Joachim Creek study reach, De Soto, Missouri, created by Kyle Hix, U.S. Geological Survey, using the Sedimentation and River Hydraulics-Two-Dimensions model. 


\section{Two-Dimensional Hydraulic Analyses of Joachim Creek, De Soto, Missouri}

By Kyle D. Hix, Paul H. Rydlund, and David C. Heimann

Prepared in cooperation with the City of De Soto, Missouri

Scientific Investigations Report 2021-5058 


\section{U.S. Geological Survey, Reston, Virginia: 2021}

For more information on the USGS - the Federal source for science about the Earth, its natural and living resources, natural hazards, and the environment—visit https://www.usgs.gov or call 1-888-ASK-USGS.

For an overview of USGS information products, including maps, imagery, and publications, visit https://store.usgs.gov/.

Any use of trade, firm, or product names is for descriptive purposes only and does not imply endorsement by the U.S. Government.

Although this information product, for the most part, is in the public domain, it also may contain copyrighted materials as noted in the text. Permission to reproduce copyrighted items must be secured from the copyright owner.

Suggested citation:

Hix, K.D., Rydlund, P.H., and Heimann, D.C., 2021, Two-dimensional hydraulic analyses of Joachim Creek, De Soto, Missouri: U.S. Geological Survey Scientific Investigations Report 2021-5058, 28 p., https://doi.org/10.3133/ sir20215058.

Associated data for this publication:

Heimann, D.C., and Hix, K.D., 2021, PeakFO software input files and selected output files for selected long-term streamgages near Jefferson County, Missouri, through water year 2019: U.S. Geological Survey data release, https:// doi.org/10.5066/P9ACXXI7.

Hix, K.D., and Heimann, D.C., 2021, Geospatial data and model archive associated with the two-dimensional hydraulic analysis of Joachim Creek, De Soto, Missouri: U.S. Geological Survey data release, https://doi.org/10.5066/ P92MQYE7.

U.S. Geological Survey, 2020, USGS water data for the Nation: U.S. Geological Survey National Water Information System database, accessed May 2020 at https://doi.org/10.5066/F7P55KJN.

ISSN 2328-0328 (online) 


\section{Acknowledgments}

The authors wish to acknowledge funding provided by the City of De Soto, Missouri, for this study along with the continued support from the City in funding the U.S. Geological Survey streamgage Joachim Creek at De Soto, Missouri (station 07019500). 



\section{Contents}

Acknowledgments ……...................................................................................................................

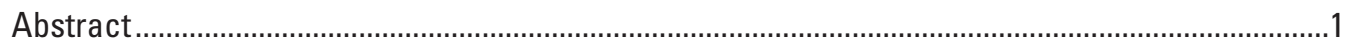

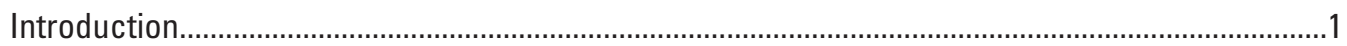

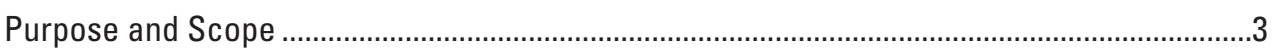

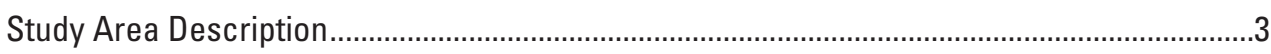

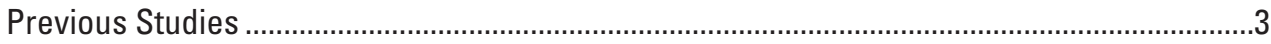

Development of Hydraulic Model .............................................................................................

Computation of Water-Surface Elevations …………………..................................................

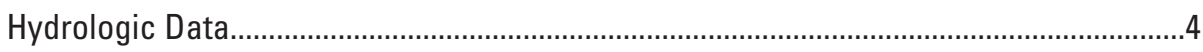

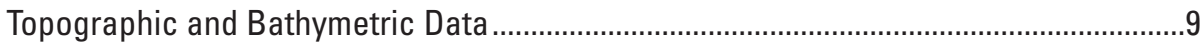

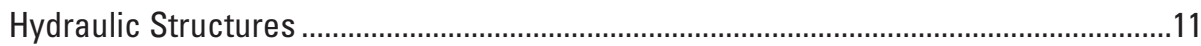

Energy-Loss Factors ..........................................................................................

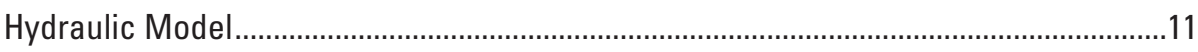

Development of Water-Surface Elevations ....................................................................12

Model Sensitivity Analysis .........................................................................................12

Development of Water-Surface Profiles and Map Products .................................................12

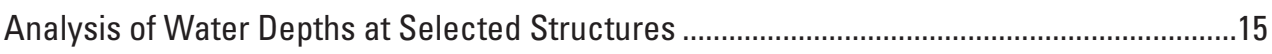

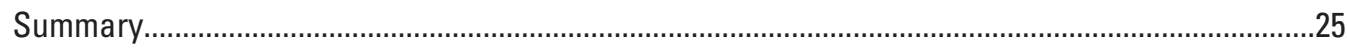

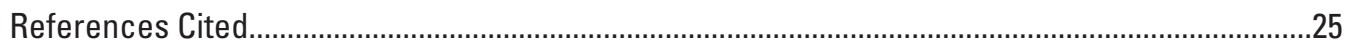

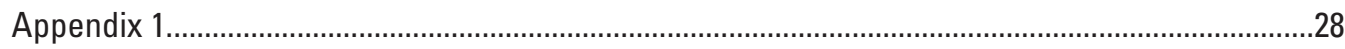

\section{Figures}

1. Map showing location of the study reach, flow-change locations used in the two-dimensional hydraulic model, and location of the cooperative U.S. Geological Survey streamgage Joachim Creek at De Soto, Missouri.

2. Map showing location of streamgages used in the development of rural-regression equations including selected streamgages near De Soto, Missouri, and hydrologic region boundaries in Missouri and neighboring States of Missouri

3. Graph showing relation between 1-percent annual exceedance probability streamflows computed from at-site streamflow analyses and those predicted from generalized-least squares regression equations for hydrologic region 2 in Missouri, including basins near Joachim Creek.

4. Graphs showing relation between drainage area and basin yield determined using 1-percent annual exceedance probability streamflows computed from at-site flood-frequency analyses at stations nearest the Joachim Creek Basin, De Soto, Missouri

5. Graph showing the 10-percent annual exceedance probability flood profile for the Joachim Creek study reach, De Soto, Missouri, from the Federal Emergency Management Agency (2019b) flood-insurance study and this study

6. Graph showing the 4-percent annual exceedance probability flood profile for the Joachim Creek study reach, De Soto, Missouri, from the Federal Emergency Management Agency (2019b) flood-insurance study and this study 
7. Graph showing the 2-percent annual exceedance probability flood profile for the Joachim Creek study reach, De Soto, Missouri, from the Federal Emergency Management Agency (2019b) flood-insurance study and this study

8. Graph showing the 1-percent annual exceedance probability flood profile for the Joachim Creek study reach, De Soto, Missouri, from the Federal Emergency Management Agency (2019b) flood-insurance study and this study ...........16

9. Graph showing the 0.2-percent annual exceedance probability flood profile for the Joachim Creek study reach, De Soto, Missouri, from the Federal Emergency Management Agency (2019b) flood-insurance study and this study ...........17

10. Map showing modeled water-surface elevations for the 1-percent annual exceedance flow in the Joachim Creek study reach, De Soto, Missouri. .18

11. Map showing modeled water velocities for the 1-percent annual exceedance flow in the Joachim Creek study reach, De Soto, Missouri 19

12. Map showing modeled water depths for the 1-percent annual exceedance flow in the Joachim Creek study reach, De Soto, Missouri

13. Map showing modeled water-surface elevations for the 0.2-percent annual exceedance flow in the Joachim Creek study reach, De Soto, Missouri

14. Map showing modeled water velocities for the 0.2-percent annual exceedance flow in the Joachim Creek study reach, De Soto, Missouri 22

15. Map showing modeled water depths for the 0.2-percent annual exceedance flow in the Joachim Creek study reach, De Soto, Missouri

\section{Tables}

1. U.S. Geological Survey streamgage information for Joachim Creek at De Soto, Missouri

2. Model flow-change locations and corresponding input streamflows for 10-, 4-, 2-, 1-, and 0.2-percent annual exceedance probabilities for the Joachim Creek study reach, De Soto, Missouri, as determined using the U.S. Geological Survey StreamStats application

3. Example of lower and upper 90-percent prediction limits of uncertainty in streamflow estimates determined for the Joachim Creek study reach, De Soto, Missouri, using rural-regression equations developed by Southard and Veilleux (2014)

4. Basin yields for 1-percent annual exceedance probability peak streamflows calculated from U.S. Geological Survey StreamStats peak-flow estimates at selected locations along Joachim Creek, De Soto, Missouri ...

5. Basin yields for 1-percent annual exceedance probability peak streamflows for stations within hydrologic response region 2 with drainage areas comparable to those in the Joachim Creek study reach, De Soto, Missouri..

6. Station and rural-regression 1-percent annual exceedance probability flows for selected stations near the Joachim Creek Basin, De Soto, Missouri

7. Basin yields for 1-percent annual exceedance probability peak streamflows at selected locations along Joachim Creek, De Soto, Missouri, calculated from flood-frequency analyses from nearest stations using record through 2012 and 2019.

8. Calibration of model to target in-channel water-surface elevation at the U.S. Geological Survey streamgage Joachim Creek at De Soto, Missouri, and to selected locations along Joachim Creek for the flood of April 18, 2013. 
9. Summary of simulated water-surface elevations, relative to bridge structure thresholds, for bridges within the Joachim Creek study reach, De Soto, Missouri

\section{Conversion Factors}

U.S. customary units to International System of Units

\begin{tabular}{|c|c|c|}
\hline Multiply & By & To obtain \\
\hline \multicolumn{3}{|c|}{ Length } \\
\hline foot $(\mathrm{ft})$ & 0.3048 & meter $(\mathrm{m})$ \\
\hline mile (mi) & 1.609 & kilometer (km) \\
\hline \multicolumn{3}{|c|}{ Area } \\
\hline square mile $\left(\mathrm{mi}^{2}\right)$ & 259.0 & hectare (ha) \\
\hline square mile $\left(\mathrm{mi}^{2}\right)$ & 2.590 & square kilometer $\left(\mathrm{km}^{2}\right)$ \\
\hline \multicolumn{3}{|c|}{ Flow rate } \\
\hline cubic foot per second $\left(\mathrm{ft}^{3} / \mathrm{s}\right)$ & 0.02832 & cubic meter per second $\left(\mathrm{m}^{3} / \mathrm{s}\right)$ \\
\hline $\begin{array}{l}\text { cubic foot per second per square } \\
\text { mile }\left(\left[\mathrm{ft}^{3} / \mathrm{s}\right] / \mathrm{mi}^{2}\right)\end{array}$ & 0.01093 & $\begin{array}{l}\text { cubic meter per second per } \\
\text { square kilometer }\left(\left[\mathrm{m}^{3} / \mathrm{s}\right] / \mathrm{km}^{2}\right)\end{array}$ \\
\hline \multicolumn{3}{|c|}{ Hydraulic gradient } \\
\hline foot per mile (ft/mi) & 0.1894 & meter per kilometer (m/km) \\
\hline
\end{tabular}

\section{Datum}

Vertical coordinate information is referenced to the North American Vertical Datum of 1988 (NAVD 88).

Horizontal coordinate information is referenced to the North American Datum of 1983 (NAD 83).

Elevation, as used in this report, refers to distance above the vertical datum. 


\section{Abbreviations}

$\begin{array}{ll}\text { AEP } & \text { annual exceedance probability } \\ \text { DEM } & \text { digital elevation model } \\ \text { FIS } & \text { flood-insurance study } \\ \text { HEC-RAS } & \text { Hydrologic Engineering Center River Analysis System } \\ \text { lidar } & \text { light detection and ranging } \\ n & \text { Manning's roughness coefficient } \\ \text { SMS } & \text { Surface-water Modeling System } \\ \text { SRH-2D } & \text { Sedimentation and River Hydraulics-Two-Dimensions model } \\ \text { USACE } & \text { U.S. Army Corps of Engineers } \\ \text { USGS } & \text { U.S. Geological Survey } \\ \text { 1D } & \text { one-dimensional }\end{array}$




\title{
Two-Dimensional Hydraulic Analyses of Joachim Creek, De Soto, Missouri
}

\author{
By Kyle D. Hix, Paul H. Rydlund, and David C. Heimann
}

\section{Abstract}

A two-dimensional hydraulic model; water-surface profiles; and digital maps of water-surface elevation, velocities, and water depths were developed for a 6.7-mile reach of Joachim Creek within and near the city of De Soto, Missouri. Water-surface profiles were generated for the 10-, 4-, 2-, 1-, and 0.2-percent annual exceedance probability (10-, 25-, 50-, 100-, and 500-year recurrence interval) flows. Digital maps of water-surface elevation, water depth, and velocity were generated for the 1- and 0.2-percent annual exceedance probability flows. Water-surface elevations and inundation extents of generated profiles and maps were substantially lower than similar products produced for the 2019 flood-insurance study that included the study reach. The differences in water-surface elevations can be attributed to differences in input streamflows and hydraulic simulation techniques.

The water-surface elevations generated for the 1- and 0.2-percent annual exceedance probability flows were used to assess the vulnerability and inundation depths of 231 selected structures within the city of De Soto. Results indicate that 157 to 177 of the 231 structures were affected at the 1-percent annual exceedance probability flow, depending on the adjacent grade elevation used for reference. Between 185 and 198 structures were affected at the 0.2-percent annual exceedance probability flow, depending on grade elevation. Inundation depths at the affected structures were 0.02 to 9.28 feet (ft), depending on the flow and adjacent grade reference.

Flood elevations were computed for Joachim Creek using a two-dimensional, finite-volume numerical modeling application for river hydraulics. The hydraulic model was calibrated using high-water marks from the April 18, 2013, flood and the maximum measured streamflow at the U.S. Geological Survey streamgage Joachim Creek at De Soto, Mo. (station 07019500), on September 8, 2018. The calibrated model was then used to compute the hydraulic conditions associated with the 10-, 4-, 2-, 1-, and 0.2-percent annual exceedance probability flows. The simulated water-surface elevations and digital elevation model (derived from light detection and ranging data having a $0.60-\mathrm{ft}$ vertical accuracy and a $1.97-\mathrm{ft}$ horizontal resolution) were used to generate products including water-surface profiles and maps of inundated area, water depth, and velocities using model postprocessing software.

\section{Introduction}

The city of De Soto (fig. 1), Missouri, has experienced substantial flooding from Joachim Creek and joining tributaries throughout the corporate limits in recent years. Flooding in April 2013, May 2013, August 2016, and April 2017 has affected the community, leading to one fatality and elevating risk to first responders from a local rural firehouse (located in the floodway). Recent developments such as a local flood warning and mapping system (Heimann and others, 2019), an effective flood-insurance study (FIS) with accompanying flood-insurance rate maps (Federal Emergency Management Agency, 2019b), and a proposed floodplain management plan (U.S. Army Corps of Engineers, 2019) have helped mitigate risk within the city of De Soto.

Development of community ordinances in compliance with the National Flood Insurance Program requires an understanding of floodplain management and a high degree of certainty in flood analysis to support and implement the ordinances. More specifically, verification and certainty in the effects of flooding to local businesses and residents are vital to the sustainability and future growth of the community. Therefore, the U.S. Geological Survey (USGS), in cooperation with the City of De Soto developed a detailed hydrologic and hydraulic analyses of Joachim Creek to have a better understanding and verification of the existing regulatory floodplain. Analyses included the use of existing USGS streamgage Joachim Creek at De Soto, Mo. (station 07019500); development and analyses of flood-frequency streamflows; and hydraulic simulations of the 10-, 4-, 2-, 1-, and 0.2-percent annual exceedance probability (AEP) regulatory floods corresponding to 10-, 25-, 50-, 100-, and 500-year recurrence interval floods, respectively. The results for each hydraulic simulation included water-surface elevation computations, although the 1- and 0.2-percent AEP flood analyses also included water velocities and depths. The information from these analyses can be used by managers, engineers, and planners to make informed floodplain management decisions regarding risk and mitigation. 


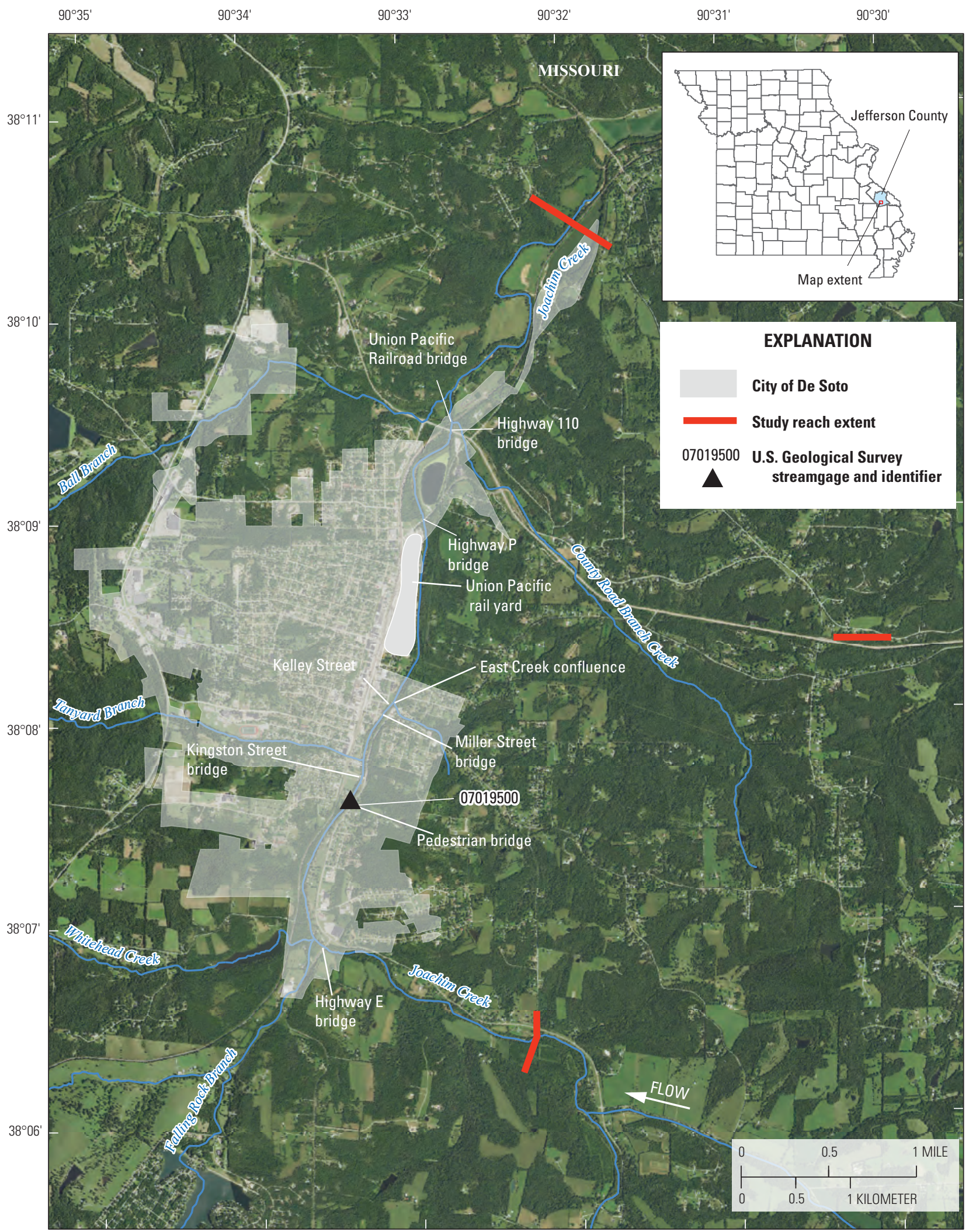

Base from Farm Service Agency, National Agricultural Imagery Program, 2016

Universal Transverse Mercator projection, zone 15 North

Horizontal coordinate information referenced to the

North American Datum of 1983 (NAD 83)

Figure 1. Location of the study reach, flow-change locations used in the two-dimensional hydraulic model, and location of the cooperative U.S. Geological Survey streamgage Joachim Creek at De Soto, Missouri (station 07019500). 


\section{Purpose and Scope}

The purpose of this report is to describe the development of a series of flood water-surface profiles, and maps of hydraulic characteristics, for selected regulatory flows for a reach of Joachim Creek in De Soto. Results from the simulation of the 1- and 0.2-percent AEP flows are used to assess the effects of flooding on selected structures within the city of De Soto. The techniques and hydrologic input data used in this study, and the corresponding results, were generated as an alternative and independent interpretation to the probabilistic streamflows and simulated consequences of these flows from results provided by the most recently published FIS (Federal Emergency Management Agency, 2019b). The profiles and maps were produced for flows corresponding to the 10-, 4-, 2-, 1 -, and 0.2-percent AEPs and corresponding water levels referenced to the stage recorded at the USGS streamgage Joachim Creek at De Soto (station 07019500; table 1); the streamgage is about $2.4 \mathrm{mi}$ downstream from the upstream extent of the study reach (fig. 1). The products from this study cover a range in stage from 10.57 to 17.53 feet (ft), referenced to the streamgage datum, and correspond to a range from about the National Weather Service flood stage of $10 \mathrm{ft}$ to $4.53 \mathrm{ft}$ greater than the major flood stage of $13 \mathrm{ft}$.

\section{Study Area Description}

The Joachim Creek study reach is in Jefferson County in east-central Missouri and is mostly within the city limits of De Soto (fig. 1). The 6.7-mi study reach extends from 1.3 mi upstream from the De Soto, Mo., city boundary downstream to the approximate downstream boundary of De Soto (fig. 1). The drainage area upstream from the USGS streamgage at De Soto is 42.4 square miles $\left(\mathrm{mi}^{2}\right)$, and the drainage area at the downstream extent of the study reach is $60.8 \mathrm{mi}^{2}$. The Joachim Creek Basin is in the Ozark Plateau physiographic region (Fenneman, 1938). Land slopes in the basin are generally 3 to 10 percent with local relief of 300 to $400 \mathrm{ft}$ (Collier, 1955). The primary land cover of the study basin is forest ( 69.8 percent), followed by pasture and grasslands (17.3 percent) and open/barren land (7.3 percent), based on the 2016 National Land Cover Database (Jin and others, 2019). Less than 5 percent of the basin is classified as low- to high-intensity development. The study reach has an average top-of-bank width of $90.0 \mathrm{ft}$ and an average slope of 11.4 feet per mile based on channel cross-section data obtained from a hydraulic model of Joachim Creek (Alicia Williams, Wood Environment and Infrastructure Solutions, written commun., 2018). Minor tributaries within the reach include (from upstream to downstream) Falling Rock Branch, Whitehead Creek, Tanyard Branch, East Creek, County Road Branch, and Ball Branch (fig. 1). Most of the land contiguous to the reach within the city limits is residential or commercial. Outside of the city limits, the land use primarily is forest and pasture. There are 7 bridge crossings in the main-stem reach, which include 1 railroad, 3 State highways, and 3 county/city road crossings.

\section{Previous Studies}

The most recently published FIS for the study area, including De Soto (Federal Emergency Management Agency, 2019b), presents estimates of the peak streamflows and associated AEPs and their associated water-surface elevations at several locations along Joachim Creek. A nonregulatory study also was previously completed to represent 1 -ft incremental flood-inundation maps for the 6.7-mi study reach of Joachim Creek (Heimann and others, 2019) for stages at the USGS streamgage of 8.0 to $17.0 \mathrm{ft}$. The $8.0-\mathrm{ft}$ stage corresponds to the National Weather Service "action stage" or near-bankfull stage, and the 17.0-ft stage approximates the stage corresponding to the 0.2-percent AEP flow. Flood profiles were computed for the river reach by means of a one-dimensional (1D) stepbackwater model.

Table 1. U.S. Geological Survey streamgage information for Joachim Creek at De Soto, Missouri.

[Station location is shown in figure 1. USGS, U.S. Geological Survey; $\mathrm{mi}^{2}$, square mile; ft, foot; NAVD 88, North American Vertical Datum of 1988 ; $\mathrm{ft}^{3} / \mathrm{s}$, cubic foot per second; ${ }^{\circ}$, degree; ', minute; ", second]

\begin{tabular}{|c|c|c|c|c|c|c|c|}
\hline Station name & $\begin{array}{l}\text { USGS } \\
\text { station } \\
\text { number }\end{array}$ & $\begin{array}{c}\text { Drainage } \\
\text { area } \\
\left(\mathrm{mi}^{2}\right)\end{array}$ & Latitude & Longitude & $\begin{array}{l}\text { Period of peak- } \\
\text { flow record } \\
\text { (water years') }\end{array}$ & $\begin{array}{c}\text { Maximum recorded } \\
\text { stage (ft), streamgage } \\
\text { datum and elevation (ft } \\
\text { above NAVD 88), and } \\
\text { date }\end{array}$ & $\begin{array}{l}\text { Maximum } \\
\text { streamflow }\left(\mathrm{ft}^{3 / \mathrm{s}}\right) \\
\text { and date }\end{array}$ \\
\hline $\begin{array}{l}\text { Joachim Creek } \\
\text { at De Soto, } \\
\text { Missouri }\end{array}$ & 07019500 & 42.4 & $38^{\circ} 07^{\prime} 36^{\prime \prime}$ & $90^{\circ} 33^{\prime} 23^{\prime \prime}$ & $2018-19$ & $\begin{array}{l}{ }^{2} 14.3 \\
\quad(506.2) \\
\quad \text { April 18, } 2013\end{array}$ & $\begin{array}{l}{ }^{3} 15,000 \\
\text { April 18, } 2013\end{array}$ \\
\hline
\end{tabular}

${ }^{1}$ A water year is the 12-month period from October 1 of one year through September 30 of the following year and is designated by the calendar year in which it ends.

${ }^{2}$ Stage interpolated from observed high-water marks.

${ }^{3}$ Streamflow estimated using hydraulic model and observed high-water marks. 
The hydrologic and hydraulic analyses for the previous FIS for Jefferson County, Mo. (Federal Emergency Management Agency, 2006), included a hydraulic analysis for Joachim Creek in De Soto, which was completed by the U.S. Army Corps of Engineers (USACE), St. Louis District, in August 2002 (Federal Emergency Management Agency, 2002). An additional FIS for De Soto was completed in 1981 by Booker Associates, Inc. (Federal Emergency Management Agency, 1981), and revised by the Federal Emergency Management Agency in 1998 (Federal Emergency Management Agency, 2006).

\section{Development of Hydraulic Model}

Tasks specific to the development of the two-dimensional hydraulic model, flood profiles, map products, and structure analyses for a reach of Joachim Creek near De Soto were as follows:

1. compilation of flow data from USGS streamgage Joachim Creek at De Soto (station 07019500);

2. collection and compilation of topographic and bathymetric data and geometric data for structures and bridges along the study reach;

3. estimation of energy-loss factors (material properties or roughness coefficients) in the stream channel and floodplain;

4. computation of water-surface elevations by use of the Sedimentation and River Hydraulics-TwoDimensions river flow model (SRH-2D; Bureau of Reclamation, 2008);

5. production of estimated water-surface profiles and maps of flood inundation, water depths, and velocities for selected regulatory flows; and

6. assessment of the effects of the 1- and 0.2-percent AEP flows on selected structures within the city of De Soto.

\section{Computation of Water-Surface Elevations}

The water-surface elevations used to produce the flood products in this study were simulated using SRH-2D, version 3.2.3 (Bureau of Reclamation, 2008). SRH-2D is a two-dimensional, finite-volume numerical model for simulating flow hydraulics. It features a seamless wetting-drying algorithm that provides stability, has flexibility in mesh design and shape, and can simulate steady or unsteady flows in subcritical and critical flow regimes. The graphical user interface
Surface-water Modeling System (SMS), version 13.0.14 (Aquaveo, 2020), was used to develop model components, select model inputs, and evaluate the model results.

\section{Hydrologic Data}

The study reach includes one active USGS streamgage (Joachim Creek at De Soto, station 07019500; fig. 1, table 1), which began operation on July 17, 2018. Stage at the streamgage is measured every 5 minutes, transmitted every 15 minutes by a satellite radio in the streamgage, and made available on the internet through the USGS National Water Information System database (U.S. Geological Survey, 2020c). Stage data from this streamgage are referenced to a local datum but can be converted to water-surface elevations referenced to the North American Vertical Datum of 1988 by adding $491.90 \mathrm{ft}$. Continuous records of streamflow at the Joachim Creek streamgage are computed from a stagestreamflow relation (Turnipseed and Sauer, 2010), which has been developed for the streamgage, and are available through the USGS National Water Information System database (U.S. Geological Survey, 2020b).

The available annual peak-flow record at this station is less than the 10-year minimum record period required for the development of site-specific flood-frequency analysis (England and others, 2018). The peak flows used in this study, therefore, were determined using the USGS StreamStats application (U.S. Geological Survey, 2020a; table 2). The peak-flow component of StreamStats for Missouri was developed using regression analysis techniques, data from 278 streamgages (fig. 2), and annual peak-flow record through 2012 (Southard and Veilleux, 2014). Joachim Creek lies within the specified Ozark Plateau hydrologic region of Missouri, and flood-frequency regression equations for this region were developed using record from 135 streamgages. For the Ozark Plateau (region 2 in Southard and Veilleux [2014]), the basin characteristics determined to be statistically significant determinants of peak flows were drainage area and basin shape (squared distance of longest flow path divided by drainage area). The range of drainage areas used in the region 2 regression equations was from 0.17 to $4,008 \mathrm{mi}^{2}$, and the range of basin shape values was from 2.04 to 26.89. The range of these conditions for the Joachim Creek reach (drainage area of 41.1 to $58.8 \mathrm{mi}^{2}$; basin shape of 3.24 to 4.17 [table 2]) was within the range of basin characteristics used in generating the regression equations for this region. The resulting streamflow estimates computed with the regression equations have a quantifiable uncertainty determined by the standard error of prediction and expressed by the 90 -percent prediction interval (see example in table 3 ). The model flow-change locations developed for this study (table 2) are consistent with those used in the FIS (Federal Emergency Management Agency, 2019b). 
Table 2. Model flow-change locations and corresponding input streamflows for 10-, 4-, 2-, 1-, and 0.2-percent annual exceedance probabilities for the Joachim Creek study reach, De Soto, Missouri, as determined using the U.S. Geological Survey StreamStats application. Note: flow locations correspond to those used in the Federal Emergency Management Agency (2019b) flood-insurance study.

[mi², square mile; $\mathrm{ft}^{3} / \mathrm{s}$, cubic foot per second; RR, Railroad]

\begin{tabular}{|c|c|c|c|c|c|c|c|}
\hline \multirow{2}{*}{ Location (fig. 1) } & \multirow{2}{*}{$\begin{array}{c}\text { Drainage } \\
\text { area } \\
\left(\mathrm{mi}^{2}\right)\end{array}$} & \multirow{2}{*}{$\begin{array}{l}\text { Basin } \\
\text { shape }\end{array}$} & \multicolumn{5}{|c|}{$\begin{array}{l}\text { Annual exceedance probability streamflow } \\
\qquad\left(\mathrm{ft}^{3} / \mathrm{s}\right)\end{array}$} \\
\hline & & & 10 percent & 4 percent & 2 percent & 1 percent & 0.2 percent \\
\hline $\begin{array}{l}\text { Highway E (used as flow for } \\
\text { upstream model boundary) }\end{array}$ & 41.1 & 3.24 & 8,110 & 11,300 & 13,700 & 16,100 & 21,900 \\
\hline Kelley Street & 45.5 & 3.73 & 8,370 & 11,600 & 14,100 & 16,500 & 22,400 \\
\hline Union Pacific RR bridge & 52.5 & 4.17 & 8,950 & 12,400 & 15,000 & 17,600 & 23,800 \\
\hline $\begin{array}{l}\text { Downstream from Ball Branch } \\
\text { confluence }\end{array}$ & 58.8 & 3.83 & 9,880 & 13,700 & 16,600 & 19,500 & 26,400 \\
\hline
\end{tabular}

Table 3. Example of lower and upper 90-percent prediction limits of uncertainty in streamflow estimates determined for the Joachim Creek study reach, De Soto, Missouri, using rural-regression equations developed by Southard and Veilleux (2014).

[ $\mathrm{ft}^{3} / \mathrm{s}$, cubic foot per second]

\begin{tabular}{|c|c|c|c|c|c|}
\hline \multirow{2}{*}{ Location (fig. 1) } & \multicolumn{5}{|c|}{$\begin{array}{l}\text { Annual exceedance probability streamflow } \\
\qquad\left(\mathrm{ft}^{3} / \mathrm{s}\right)\end{array}$} \\
\hline & 10 percent & 4 percent & 2 percent & 1 percent & 0.2 percent \\
\hline Kelley Street (lower prediction interval) & 5,290 & 7,840 & 9,500 & 11,100 & 14,400 \\
\hline Kelley Street (upper prediction interval) & 13,200 & 17,200 & 20,900 & 24,600 & 34,800 \\
\hline
\end{tabular}

Because no current or historical streamgages within the Joachim Creek Basin were used in the development of the flood-frequency regression equations, an analysis of at-site derived flood-frequency flows from selected streamgages in the region (Heimann and Hix, 2021) was used to verify the application of the regression equations to this basin. A comparison of station-derived and regression equation-derived estimates of the 1-percent AEP flow for region 2 indicated strong agreement (fig. 3) and included selected basins near (within a two-county radius) Jefferson County and De Soto (fig. 2).

One means of normalizing estimates of peak streamflows for comparisons is by determining basin yields, computed as flow in cubic feet per second divided by drainage area in square miles. Unregulated basins of the same drainage area and within the same hydrologic response region should, in general, have similar yields. The peak-flow basin yield, in cubic feet per second per square mile, was determined for the 1-percent AEP streamflows generated from StreamStats for selected locations in the study reach (table 4). An initial assessment of at-site estimates of peak-flow yields for 1-percent AEP flows at stations within region 2 with similar drainage areas indicates a sizable range in yields (table 5), but Joachim Creek estimated yields (table 4) generally were within the determined range.
Basin yields also were determined from 1-percent AEP flows using at-site analyses (Southard and Veilleux, 2014) for selected stations in region 2 that were near the Joachim Creek Basin (fig. 2, table 6). A relation between drainage area and peak-flow basin yield using data from these 29 nearby stations was developed to compare yields developed using StreamStats with yields developed from at-site floodfrequency analyses (fig. 4). Stations selected for this analysis included a range of drainage areas $\left(0.22\right.$ to $\left.3,788 \mathrm{mi}^{2}\right)$ such that the relation derived from the yields of the peak-flow estimates could be compared to the range of drainage areas corresponding to the selected locations in the Joachim Creek Basin. The relation between drainage area and peak-flow yield was used to estimate yields for the range of drainage areas within the Joachim Creek study reach (41.1 to $58.8 \mathrm{mi}^{2}$; table 7). The peak-streamflow yields from the StreamStats estimates for five locations in the Joachim Creek Basin were 391.7 to 331.6 cubic feet per second per square mile $\left(\left[\mathrm{ft}^{3} / \mathrm{s}\right] /\right.$ $\mathrm{mi}^{2}$ ) corresponding to drainage areas of 41.1 to $58.8 \mathrm{mi}^{2}$ (table 4). Basin yields for drainage areas corresponding to the selected study reach locations and computed using the 2012 station-based relations were 272.8 to $310.0\left(\mathrm{ft}^{3} / \mathrm{s}\right) / \mathrm{mi}^{2}$; a -15.2- to -20.8-percent difference from the StreamStats estimates. 


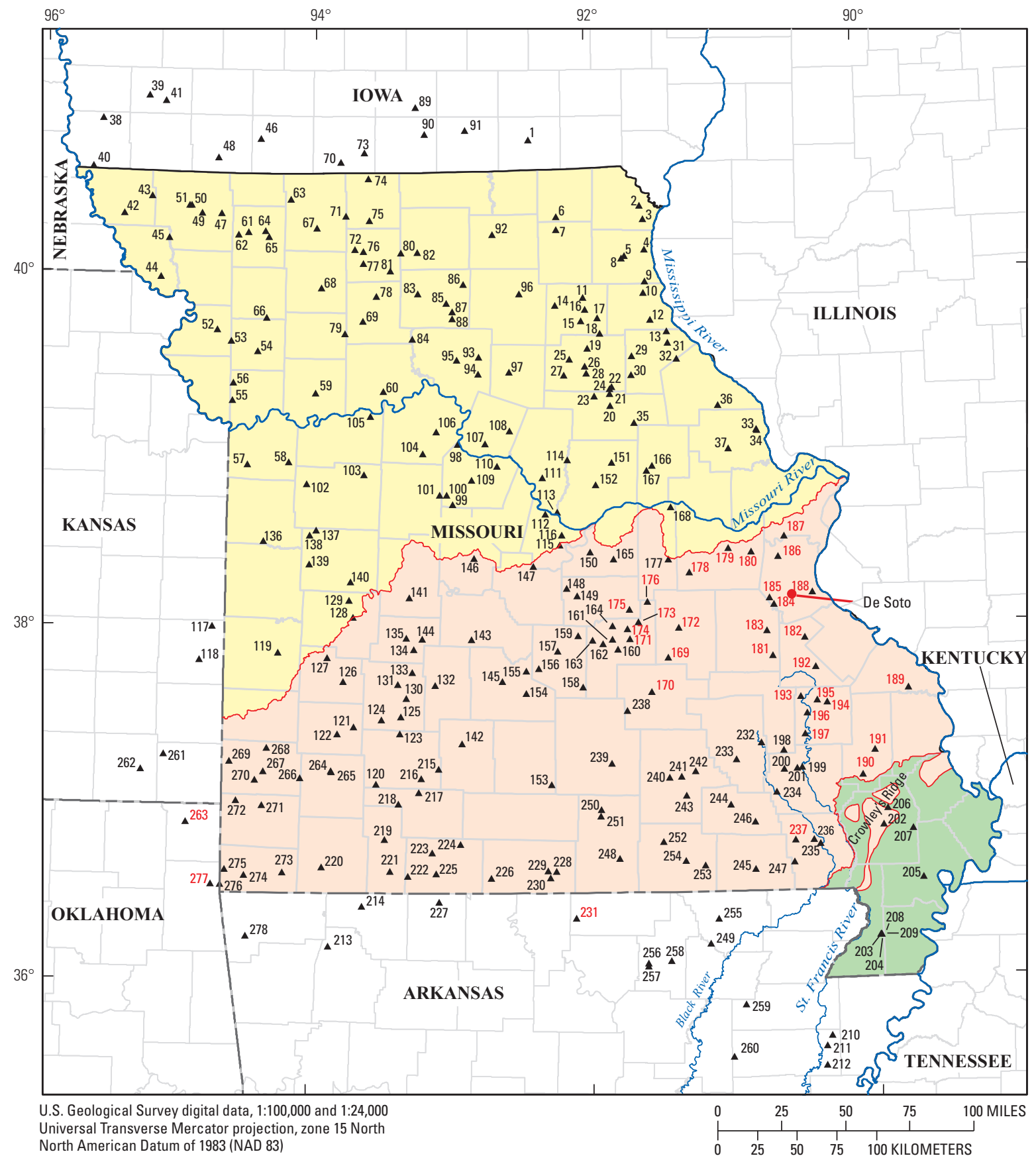

EXPLANATION

Region $175 \Delta$ U.S. Geological Survey streamgage and map

Region 2 number used in regional regression analyses (see Southard and Veilleux, 2014)

Region 3231 ॥ U.S. Geological Survey streamgage and map number (tables 5-6) used in basin yield analyses

Figure 2. Location of streamgages used in the development of rural-regression equations including selected streamgages near De Soto, Missouri, and hydrologic region boundaries in Missouri and neighboring States of Missouri (modified from Southard and Veilleux, 2014). 


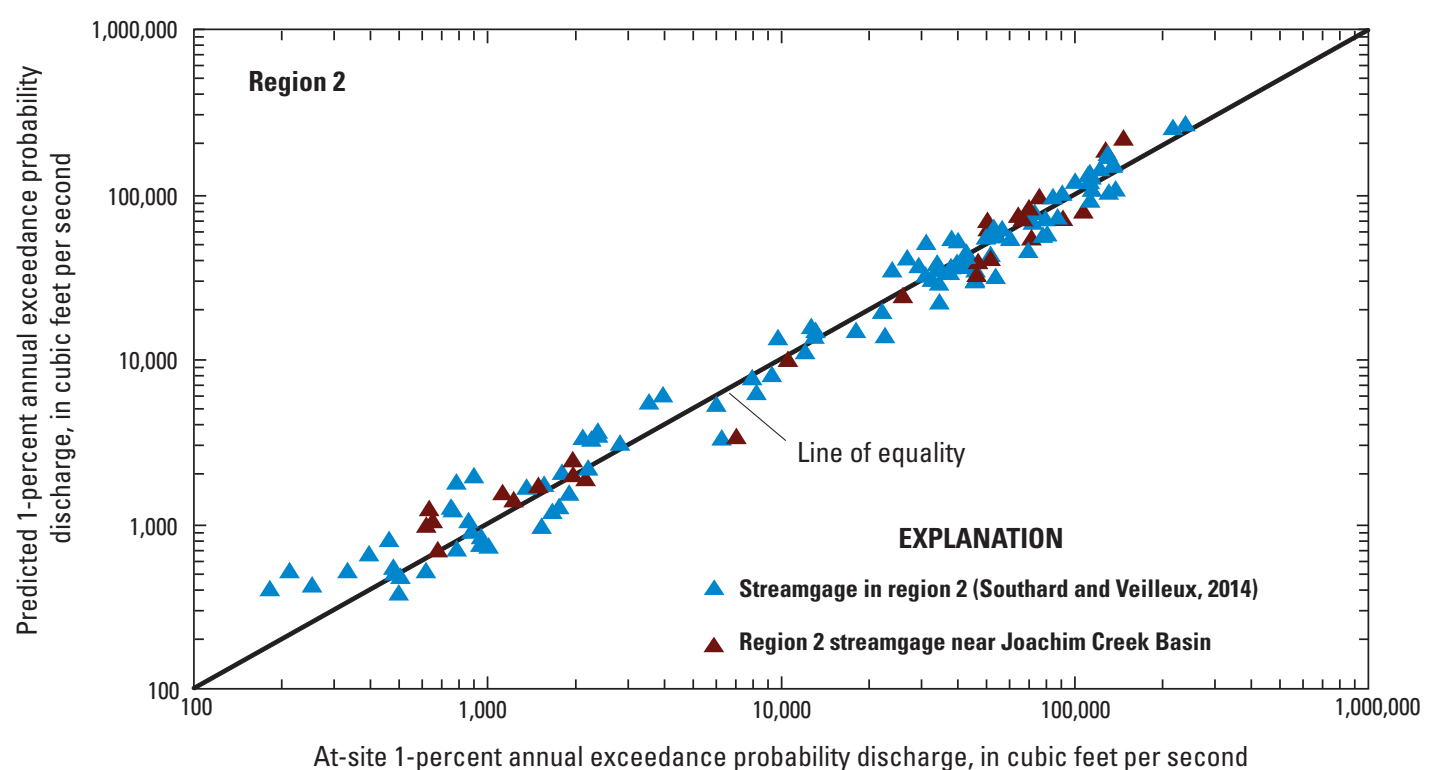

Figure 3. Relation between 1-percent annual exceedance probability streamflows computed from at-site streamflow analyses and those predicted from generalized-least squares regression equations for hydrologic region 2 (Ozark Plateau) in Missouri, including basins near Joachim Creek.

Table 4. Basin yields for 1-percent annual exceedance probability peak streamflows calculated from U.S. Geological Survey StreamStats peak-flow estimates at selected locations along Joachim Creek, De Soto, Missouri.

$\left[\mathrm{mi}^{2}\right.$, square mile; $\mathrm{ft}^{3} / \mathrm{s}$, cubic foot per second; $\left(\mathrm{ft}^{3} / \mathrm{s}\right) / \mathrm{mi}^{2}$, cubic foot per second per square mile; RR, Railroad]

\begin{tabular}{lccccc}
\hline \multicolumn{1}{c}{ Location } & $\begin{array}{c}\text { Drainage } \\
\text { area } \\
\left(\mathbf{m i}^{2}\right)\end{array}$ & $\begin{array}{c}\text { StreamStats } \\
\text { peak-flow estimate } \\
\left(\mathbf{f t}^{3} / \mathbf{s}\right)\end{array}$ & $\begin{array}{c}\text { StreamStats } \\
\text { estimate yield } \\
\left(\left[\mathrm{ft}^{3} / \mathbf{s}\right] / \mathbf{m i}^{2}\right)\end{array}$ & $\begin{array}{c}\text { StreamStats } \\
\text { lower prediction } \\
\text { interval yield } \\
\left([\mathbf{f t} / \mathbf{s}] / \mathbf{m i}^{2}\right)\end{array}$ & $\begin{array}{c}\text { StreamStats } \\
\text { upper prediction } \\
\text { interval yield } \\
\left(\left[\mathrm{ft}^{3} / \mathbf{s}\right] / \mathbf{m i}^{2}\right)\end{array}$ \\
\hline Highway E & 41.1 & 16,100 & 391.7 & 262.7 & 583.9 \\
Pedestrian bridge & 42.4 & 16,100 & 379.7 & 254.7 & 563.7 \\
Kelley Street & 45.5 & 16,500 & 362.6 & 244.0 & 540.6 \\
Union Pacific RR bridge & 52.5 & 17,600 & 335.2 & 226.7 & 497.1 \\
Ball Branch confluence & 58.8 & 19,500 & 331.6 & 222.8 & 493.2 \\
\hline
\end{tabular}

Table 5. Basin yields for 1-percent annual exceedance probability peak streamflows for stations within hydrologic response region 2 (Southard and Veilleux, 2014) with drainage areas comparable to those in the Joachim Creek study reach, De Soto, Missouri.

[ID, identifier; USGS, U.S. Geological Survey; $\mathrm{mi}^{2}$, square mile; AEP, annual exceedance probability; ft $3 / \mathrm{s}$, cubic foot per second; ( $\left(\mathrm{ft}^{3} / \mathrm{s}\right) / \mathrm{mi}^{2}$, cubic foot per second per square mile]

\begin{tabular}{cclccc}
\hline Map ID & $\begin{array}{c}\text { USGS } \\
\text { station } \\
\text { number }\end{array}$ & \multicolumn{1}{c}{ Station name } & $\begin{array}{c}\text { Drainage area } \\
\left(\mathbf{m i}^{2}\right)\end{array}$ & $\begin{array}{c}\text { At-site 1-percent } \\
\text { AEP peak-flow } \\
\text { estimate } \\
\left(\mathbf{f t}^{3} / \mathbf{s}\right)\end{array}$ & $\begin{array}{c}\text { Peak-flow } \\
\text { yield } \\
\left(\left[\mathbf{f t}^{3} / \mathbf{s}\right] / \mathbf{m i}^{2}\right)\end{array}$ \\
\hline 192 & 07033000 & Wolf Creek near Farmington, Missouri & 40.3 & 12,700 & 315.1 \\
231 & 07059450 & Big Creek near Elizabeth, Arkansas & 51.9 & 9,800 & 188.8 \\
237 & 07063470 & Tenmile Creek near Poplar Bluff, Missouri & 59.0 & 22,600 & 383.0 \\
263 & 07185095 & Tar Creek at 22nd Street Bridge at Miami, Oklahoma & 44.7 & 13,100 & 293.1 \\
277 & 07189542 & Honey Creek near South West City, Missouri & 48.2 & 18,000 & 373.4 \\
\hline
\end{tabular}


Table 6. Station (expected moments algorithm) and rural-regression 1-percent annual exceedance probability flows for selected stations near the Joachim Creek Basin, De Soto, Missouri.

$\left[\mathrm{mi}^{2}\right.$, square mile; EMA/MGB, expected moments algorithm with multiple Grubb-Beck low outlier test estimates; RRE, rural-regression equation estimates; $\mathrm{ft}^{3} / \mathrm{s}$, cubic foot per second; $\left(\mathrm{ft}^{3} / \mathrm{s}\right) / \mathrm{mi}^{2}$, cubic foot per second per square mile; --, no data or not applicable]

\begin{tabular}{|c|c|c|c|c|c|c|c|}
\hline \multirow{3}{*}{$\begin{array}{l}\text { Map ID } \\
\text { (fig. 2) }\end{array}$} & \multirow{3}{*}{$\begin{array}{c}\text { Drainage } \\
\text { area } \\
\left(\mathbf{m i}^{2}\right)\end{array}$} & \multirow{3}{*}{ Station } & \multicolumn{5}{|c|}{ 1-percent annual exceedance probability discharge, in cubic feet per second } \\
\hline & & & \multicolumn{2}{|c|}{ 1Through 2012} & \multicolumn{2}{|c|}{ Through 2019} & \multirow{2}{*}{$\begin{array}{l}\text { RRE flow } \\
\left(\mathrm{ft}^{3} / \mathrm{s}\right)\end{array}$} \\
\hline & & & $\begin{array}{c}\text { EMA/MGB flow } \\
\left(f \mathrm{ft}^{3} / \mathrm{s}\right)\end{array}$ & $\begin{array}{c}\text { Yield, } \\
\left(\left[\mathrm{ft}^{3} / \mathrm{s}\right] / \mathrm{mi}^{2}\right)\end{array}$ & $\begin{array}{c}\text { EMA/MGB flow } \\
\left(\mathrm{ft}^{3} / \mathrm{s}\right)\end{array}$ & $\begin{array}{c}\text { Yield } \\
\left(\left[\mathrm{ft}^{3} / \mathbf{s}\right] / \mathrm{mi}^{2}\right)\end{array}$ & \\
\hline 169 & 199 & 07010350 & 42,400 & 213 & 47,200 & 237 & 36,800 \\
\hline 170 & 0.89 & 07011200 & 633 & 711 & -- & -- & 1,240 \\
\hline 171 & 1.05 & 07012000 & 1,670 & 1,590 & -- & -- & 1,190 \\
\hline 172 & 781 & 07013000 & 69,200 & 88.6 & 72,200 & 92.5 & 75,200 \\
\hline 173 & 21.3 & 07015000 & 12,100 & 568 & -- & -- & 11,200 \\
\hline 174 & 0.22 & 07015500 & 212 & 964 & -- & -- & 521 \\
\hline 175 & 24.1 & 07015700 & 10,600 & 440 & -- & -- & 10,000 \\
\hline 176 & 135 & 07015720 & 46,200 & 342 & 47,700 & 353 & 35,100 \\
\hline 177 & 0.64 & 07015800 & 652 & 1,020 & -- & -- & 1,050 \\
\hline 178 & 608 & 07016000 & 50,600 & 83.2 & -- & -- & 69,900 \\
\hline 179 & 808 & 07016500 & 50,800 & 62.9 & 55,000 & 68.1 & 62,300 \\
\hline 180 & 2,673 & 07017000 & 131,000 & 49.0 & -- & -- & 171,000 \\
\hline 181 & 175 & 07017200 & 52,000 & 297 & 54,100 & 309 & 43,500 \\
\hline 182 & 3.35 & 07017500 & 1,960 & 585 & -- & -- & 2,460 \\
\hline 183 & 2.16 & 07017700 & 1,960 & 907 & -- & -- & 2,000 \\
\hline 184 & 718 & 07018000 & 73,500 & 102 & -- & -- & 78,000 \\
\hline 185 & 735 & 07018100 & 68,200 & 92.8 & 274,700 & 102 & 76,800 \\
\hline 186 & 917 & 07018500 & 64,500 & 70.3 & -- & -- & 75,200 \\
\hline 187 & 3,788 & 07019000 & 147,000 & 38.8 & 159,000 & 42.0 & 221,000 \\
\hline 188 & 0.44 & 07019820 & 678 & 1,540 & -- & -- & 698 \\
\hline 189 & 1.66 & 07020700 & 2,160 & 1,300 & -- & -- & 1,890 \\
\hline 190 & 423 & 07021000 & 71,500 & 169 & 278,700 & 186 & 54,800 \\
\hline 191 & 0.52 & 07021200 & 619 & 1,190 & -- & -- & 983 \\
\hline 192 & 40.3 & 07033000 & 12,700 & 315 & -- & -- & 15,900 \\
\hline 193 & 234 & 07034000 & 47,100 & 201 & -- & -- & 39,300 \\
\hline 194 & 90.5 & 07033500 & 26,100 & 288 & -- & -- & 24,500 \\
\hline 195 & 4.03 & 07035500 & 7,070 & 1,750 & -- & -- & 3,410 \\
\hline 196 & 505 & 07035800 & 91,700 & 182 & 293,400 & 185 & 71,800 \\
\hline 197 & 664 & 07036100 & 108,000 & 163 & ${ }^{2} 115,000$ & 173 & 79,900 \\
\hline
\end{tabular}

${ }^{1}$ Data from Southard and Veilleux (2014).

${ }^{2}$ Estimated using peak streamflow data through 2017.

Stations used in Southard and Veilleux (2014) had at least 10 years of record, and stations used in this analysis had an average of 38 years of record through 2012. Record flooding has occurred in east-central Missouri since 2012 and within the hydrologic region of interest, record flooding has occurred in 2015 (Holmes and others, 2016) and 2017 (Heimann and others, 2018). The annual peak streamflows from these flood years could substantially affect the flood-frequency estimates and, therefore, calculated peakflow yields. To maximize the accuracy of the station floodfrequency estimates for this study, and to determine the potential effect of recent floods on flood-frequency estimates, the flood-frequency flows for the 29 stations used in figure $4 \mathrm{~A}$ were updated using available record through 2019 (table 6). The station-determined flood-frequency and basin yield estimates were computed using USGS PeakFQ software, 
Table 7. Basin yields for 1-percent annual exceedance probability peak streamflows at selected locations along Joachim Creek, De Soto, Missouri, calculated from flood-frequency analyses from nearest stations (with peak record greater than 10 years) using record through 2012 and 2019.

$\left[\mathrm{mi}^{2}\right.$, square mile; $\left(\mathrm{ft}^{3} / \mathrm{s}\right) / \mathrm{mi}^{2}$, cubic foot per second per square mile; $\mathrm{ft}$, foot; RR, Railroad]

\begin{tabular}{lccc}
\hline \multicolumn{1}{c}{ Location } & $\begin{array}{c}\text { Drainage area } \\
\left(\mathbf{m i}^{2}\right)\end{array}$ & $\begin{array}{c}\text { Estimated yield using peak- } \\
\text { flow record through 2012 } \\
\left(\left[\mathrm{ft}^{3} \mathbf{3} \mathbf{s}\right] / \mathbf{m i}^{2}\right)\end{array}$ & $\begin{array}{c}\text { Estimated yield using peak- } \\
\text { flow record through 2019 } \\
\left(\left[\mathrm{ft} \mathbf{t}^{3} \mathbf{s}\right] \mathbf{m} \mathbf{m i}^{2}\right)\end{array}$ \\
\hline Highway E (500 ft downstream) & 41.1 & 310.0 & 316.8 \\
Pedestrian bridge & 42.4 & 306.6 & 313.4 \\
Kelley Street & 45.5 & 299.0 & 305.7 \\
Union Pacific RR bridge & 52.5 & 284.1 & 290.7 \\
Downstream from Ball Branch confluence & 58.8 & 272.8 & 279.4 \\
\hline
\end{tabular}

version 7.3 (Flynn and others, 2006), with a regional skew estimate of -0.30 for Missouri (Southard and Veilleux, 2014). If no peak-flow record existed past 2012 at a station, the 2012 estimate was again included in the 2019 analysis. The updated peak-flow estimates were used to develop a second relation between drainage area and basin yield and to determine updated yield estimates for drainages corresponding to the selected locations within the Joachim Creek Basin (fig. 4B, table 7). Basin yields for drainage areas corresponding to the selected study reach locations computed using station record through 2019 were 279.4 to $316.8\left(\mathrm{ft}^{3} / \mathrm{s}\right) / \mathrm{mi}^{2} ; \mathrm{a}-13.2$ - to -19.1-percent difference from the StreamStats estimates. The overall results indicate that the StreamStats utility using regional regression analyses through 2012 (and updated through 2019 at selected locations) provides a conservatively high estimate of peak streamflows and basin yields compared to nearby station-derived flood-frequency estimates using long-term (average of 66 years) peak-flow record. The differences between yield estimates using nearby at-site station analyses and those determined from StreamStats were well within the prediction interval ranges of the StreamStats yields (table 4). The StreamStats-derived peak-flow values were used in the hydraulic model, as discussed in the following sections.

\section{Topographic and Bathymetric Data}

Cross-section elevation data were obtained from a digital elevation model (DEM) that was derived from light detection and ranging (lidar) data that were collected during December 2010 by Surdex Corporation, Chesterfield, Mo., through a contract with the USACE, St. Louis Division. The data were postprocessed by Surdex Corporation on April 6, 2011 (Missouri Spatial Data Information Service, 2019a). The bare-earth lidar data were processed using USGS Base Lidar Specifications, version 1.3 (Heidemann, 2018), that met or exceeded the National Map Accuracy Standards for vertical and horizontal accuracy guidelines for 2 - $\mathrm{ft}$ contours (American Society for Photogrammetry and Remote Sensing,
$1990,2004)$. The lidar data have a horizontal accuracy of a 1.97 -ft (60-centimeter) root mean squared error and a vertical accuracy of a $0.607-\mathrm{ft}$ (18.5-centimeter) root mean squared error.

The final DEM, which was resampled to a $3.28-\mathrm{ft}$ grid-cell size to decrease the geographic information system processing time, has a vertical accuracy of plus or minus $1 \mathrm{ft}$. Any development or landscape modifications within the Joachim Creek floodplain that took place after the lidar was flown (December 2010) and that could result in substantial topographic and hydraulic changes to the floodplain were considered for inclusion in the DEM. For example, modifications within the Union Pacific rail yard in De Soto (fig. 1) and at locations of selected nonstructural assets were surveyed and incorporated into the DEM and interpolated onto the model mesh. The lidar-derived DEM was supplemented with field data from the rail yard and structures. The field data were collected by a modified Level II Global Navigation Satellite Systems survey (Rydlund and Densmore, 2012) along the profile of a berm on the south end of the Union Pacific rail yard and at 231 structures within De Soto. The highest adjacent grade and lowest adjacent grade (highest and lowest elevation of ground adjacent to structure) were collected for each structure. The grade values of the 231 structures and surveyed points from the rail yard berm were merged into the final DEM.

Lidar data typically cannot provide ground elevations below the water surface of a stream; therefore, channel bottom elevations also were incorporated into the DEM from channel surveys. Channel surveys of Joachim Creek, corresponding to cross-section locations in the USACE Hydrologic Engineering Center River Analysis System (HEC-RAS) model used in a previous flood-inundation mapping study (Heimann and others, 2019), were surveyed by Wood Environment and Infrastructure Solutions during 2015 (Alicia Williams, Wood Environment and Infrastructure Solutions, written commun., 2018) and spot verified by USGS field crews during 2018. The channel elevations were measured by wading at selected HEC-RAS model transect locations. A differential global 


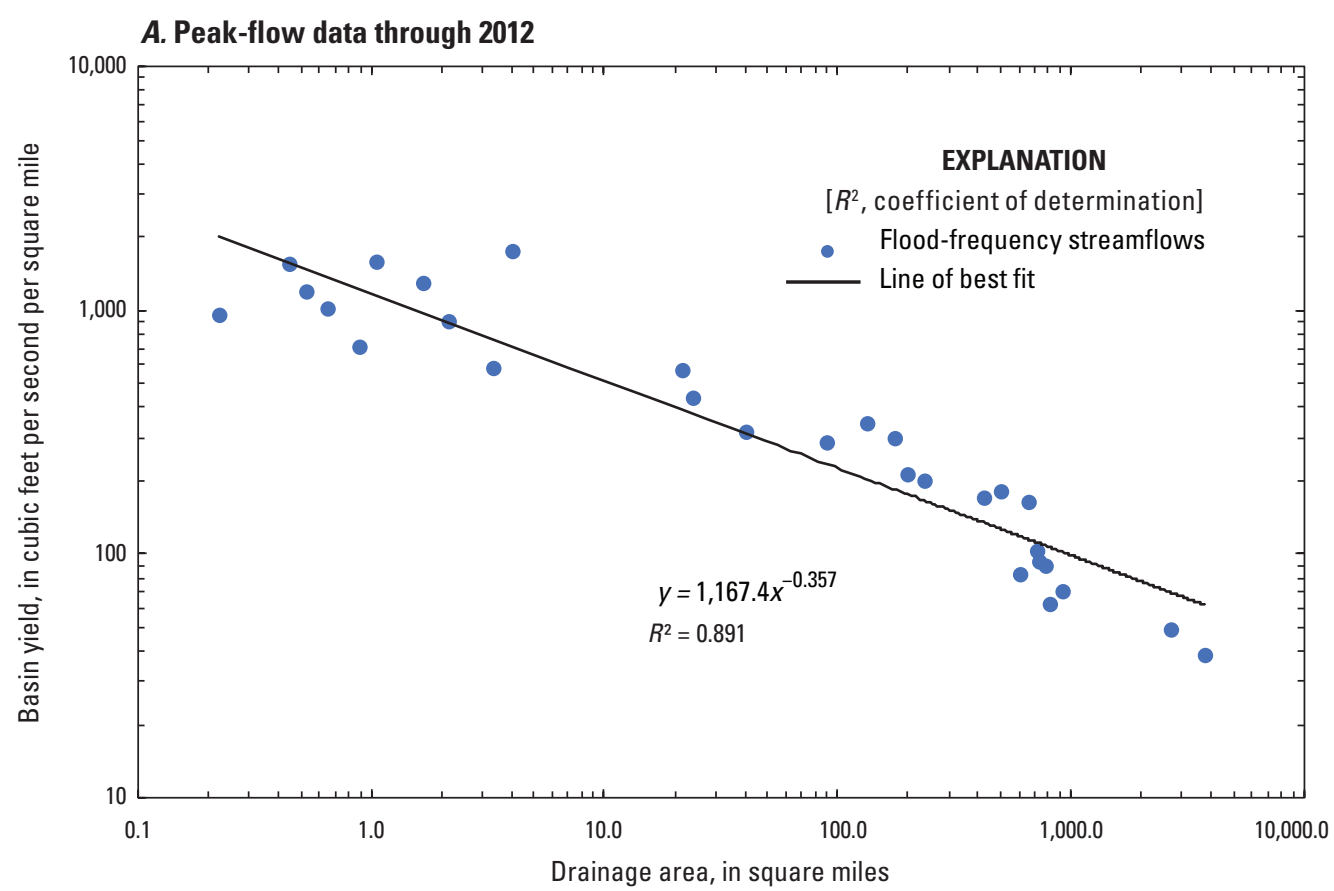

B. Peak-flow data through 2019

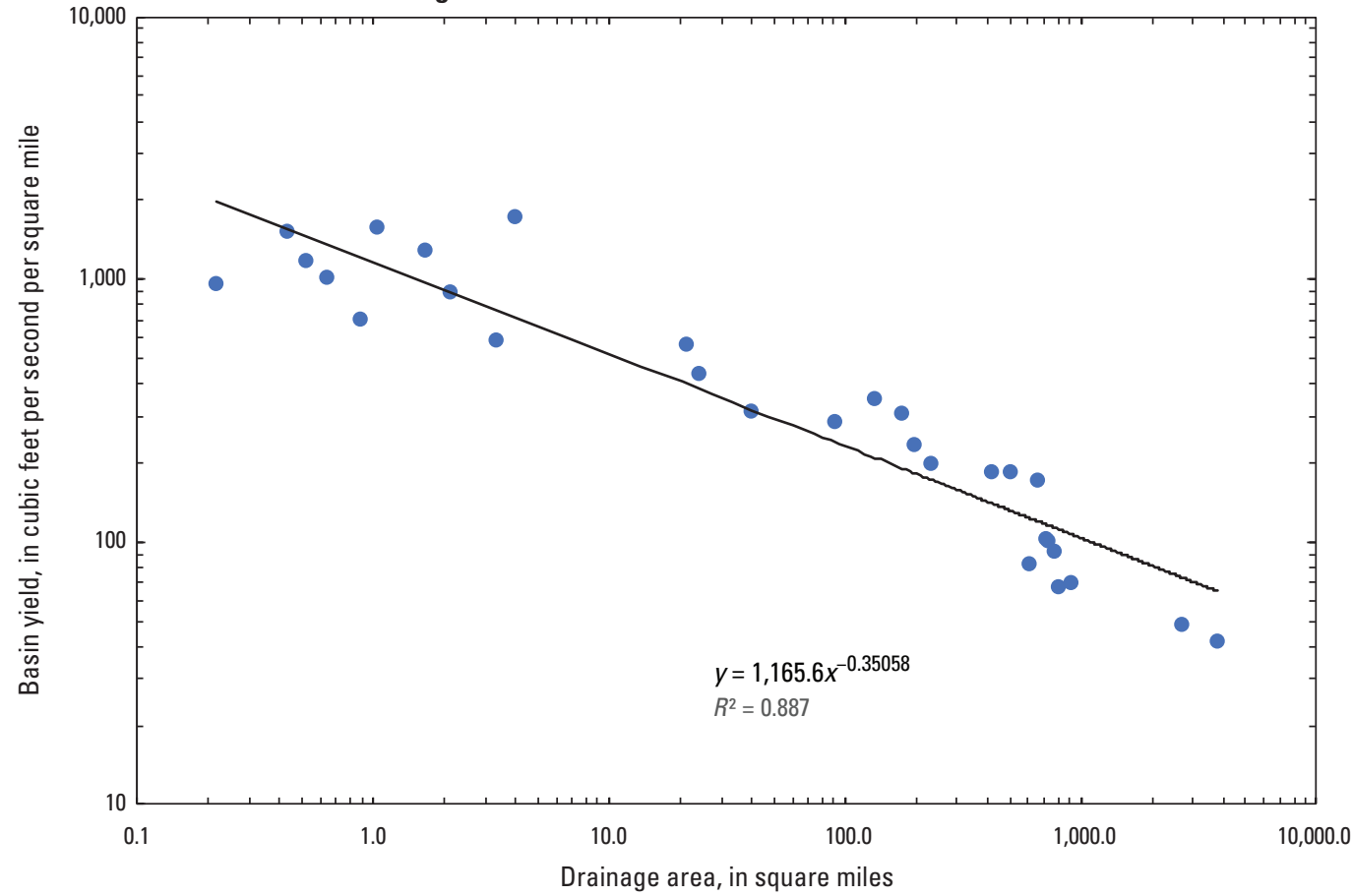

Figure 4. Relation between drainage area and basin yield determined using 1-percent annual exceedance probability streamflows computed from at-site flood-frequency analyses at stations nearest the Joachim Creek Basin, De Soto, Missouri. A, for peak-flow record through 2012; $B$, for peak-flow record through 2019. 
positioning system with real-time kinematic technology was used to derive horizontal locations and the elevation of the water surface and channel bottom at surveyed points.

\section{Hydraulic Structures}

A total of 7 structures, consisting of 6 road crossings ( 3 county road bridges and 3 State highway bridges) and 1 railroad bridge, have the potential to affect water-surface elevations during floods along the stream. Bridge-geometry data were obtained from a HEC-RAS model developed by Wood Environment and Infrastructure Solutions (Alicia Williams, Wood Environment and Infrastructure Solutions, written commun., 2018) and from as-built bridge plans. The bridgegeometry data were verified by field surveys in 2018 and 2020 by personnel from the USGS Central Midwest Water Science Center. Bridge piers were modeled as flow obstructions in SRH-2D; that is, as a hole in the mesh corresponding to the location, dimensions, and orientation of the pier. The culverts throughout the study area were modeled as bridge structures with pressure flow boundaries using the geometry data from the HEC-RAS model developed by Wood Environment and Infrastructure Solutions (Alicia Williams, Wood Environment and Infrastructure Solutions, written commun., 2018). The DEM resolution generated from lidar data was high enough to accurately capture the roadway embankments and levee elevations, and the computational mesh was created to align with the top of these features.

\section{Energy-Loss Factors}

Hydraulic analyses require the estimation of energy losses that result from frictional resistance exerted by a channel on flow. These energy losses are quantified by the Manning's roughness coefficient ( $n$-value). Initial (precalibration) $n$-values were selected using field observations, high-resolution aerial photographs (Missouri Spatial Data Information Service, 2019b), and tabulated estimates of $n$-values (Chow, 1959; Arcement and Schneider, 1989). As part of the general calibration process, the initial $n$-values were adjusted until the differences between simulated and observed water-surface elevations at the streamgage and elsewhere along the study reach were minimized. The final $n$-values ranged from 0.015 to 0.045 for the main channel and from 0.05 to 0.12 for the overbank areas modeled in this analysis. The lowest channel coefficients were placed in straight bedrock-lined reaches, and the highest were placed in low-gradient, fine-material substrate reaches with vegetated banks. The lowest floodplain coefficients were placed in open fields and the highest in densely forested areas. An $n$-value of 0.05 was selected for grassland areas, and an $n$-value of 0.09 was selected for forests and agricultural areas. The developed areas ranged from open space to highintensity development and $n$-values from 0.08 to 0.12 were selected, respectively.
The calibration process involved adjusting initial $n$-values such that the difference between the computed water-surface elevation and the observed water-surface elevation was minimized. A stage-streamflow relation is still in development for the De Soto streamgage, and the in-channel values were calibrated to the highest flow measurement at the streamgage. A flow of 5,400 cubic feet per second $\left(\mathrm{ft}^{3} / \mathrm{s}\right)$ was measured at USGS streamgage Joachim Creek at De Soto (station 07019500) on September 8, 2018, and is the highest flow measurement made with flows contained within the channel. A constant flow was used in the calibration given the lack of a rating and the midreach location of the measurement. The $n$-values were adjusted such that the water surface at the streamgage site matched the observed water surface for the streamflow. The calibration of the overbank material properties followed a similar process. The overbank $n$-values were calibrated to the April 18, 2013, flood event. The overbank condition calibration was completed using an estimated constant streamflow of $15,000 \mathrm{ft}^{3} / \mathrm{s}$, consistent with the 1D model calibration in Heimann and others (2018), and high-water marks collected along the length of the study reach. The estimated constant flow of $15,000 \mathrm{ft}^{3} / \mathrm{s}$ was determined from "splitting" the high-water marks during the $1 \mathrm{D}$ calibration. The modification of $n$-values during the calibration process for the in-channel and overbank components was repeated until all the simulated and observed values at the marks were within $0.5 \mathrm{ft}$.

\section{Hydraulic Model}

Hydraulic analyses were completed using the twodimensional model SRH-2D, version 3.2.3 (Bureau of Reclamation, 2008), in steady-state flow conditions (constant streamflows). The computational mesh consisted of 45,364 nodes (points) that were connected to form 75,758 elements (cells). Elements in the channel and on man-made structures primarily were quadrilateral in shape and aligned such that the structures were well represented. Elements in the floodplain and remaining upland areas were triangular. The downstream boundary condition for each simulation was the normal-depth water surface determined within the preprocessing and model development software SMS, version 13.0.14. The upstream boundary condition was the constant peak streamflows for the given event. The flows used for each event and flow-change locations were discussed in the "Hydrologic Data" section and provided in table 2.

The SRH-2D model was calibrated to the highest stagestreamflow measurements made at the USGS streamgage Joachim Creek at De Soto (station 07019500) and to highwater marks from the April 18, 2013, flood. The computed water surface for the in-channel flow calibration, corresponding to the highest stage-streamflow measurement at the streamgage, was within $0.36 \mathrm{ft}$ of the observed water surface (table 8). For the April 18, 2013, flood, the average difference between the computed water surface and observed water 
Table 8. Calibration of model to target in-channel water-surface elevation at the U.S. Geological Survey streamgage Joachim Creek at De Soto, Missouri (station 07019500), and to selected locations along Joachim Creek for the flood of April 18, 2013.

[ft, foot; $\mathrm{ft}^{3} / \mathrm{s}$, cubic foot per second; USGS, U.S. Geological Survey; HWM, high-water mark]

\begin{tabular}{|c|c|c|c|c|c|}
\hline $\begin{array}{c}\text { Location } \\
\text { (distance from upstream } \\
\text { boundary, } \mathrm{ft} \text { ) }\end{array}$ & $\begin{array}{c}\text { Latitude } \\
\text { (decimal degrees) }\end{array}$ & $\begin{array}{c}\text { Longitude } \\
\text { (decimal degrees) }\end{array}$ & $\begin{array}{c}\text { Observed } \\
\text { water-surface } \\
\text { elevation (ft) }\end{array}$ & $\begin{array}{l}\text { Simulated water- } \\
\text { surface elevation } \\
\text { (ft) }\end{array}$ & $\begin{array}{l}\text { Difference between } \\
\text { observed and simulated } \\
\text { water surfaces (ft) }\end{array}$ \\
\hline \multicolumn{6}{|c|}{ In-channel calibration to maximum measured streamflow of 5,400 ft³/s on September 8, 2018} \\
\hline USGS streamgage & 38.12688 & -90.5566 & 499.90 & 500.26 & 0.36 \\
\hline \multicolumn{6}{|c|}{ April 18,2013 , flood peak of $15,000 \mathrm{ft}^{3} / \mathrm{s}$} \\
\hline HWM $1(5,059)$ & 38.11236 & -90.5526 & 527.56 & 527.71 & 0.15 \\
\hline HWM $3(15,035)$ & 38.13274 & -90.5555 & 501.96 & 501.48 & -0.48 \\
\hline HWM $4(15,546)$ & 38.13378 & -90.5540 & 501.03 & 501.29 & 0.26 \\
\hline HWM $5(16,861)$ & 38.13705 & -90.5527 & 496.85 & 496.90 & 0.05 \\
\hline HWM $6(23,970)$ & 38.15473 & -90.5501 & 481.76 & 481.99 & 0.23 \\
\hline
\end{tabular}

surface at the high-water marks was $-0.02 \mathrm{ft}$ and ranged from -0.48 to $0.26 \mathrm{ft}$. The calibration results indicate that the model accurately computes water-surface elevations for a wide range of flows.

\section{Development of Water-Surface Elevations}

The calibrated hydraulic model was used to generate water-surface profiles for the 10-, 4-, 2-, 1-, and 0.2-percent AEP flows (table 2) corresponding to stages from 10.57 to $17.53 \mathrm{ft}$ as referenced to the local datum of the Joachim Creek at De Soto streamgage. These stages correspond to elevations of $502.47 \mathrm{ft}$ and $509.43 \mathrm{ft}$ above the North American Vertical Datum of 1988, respectively. The regulatory flows were obtained using the USGS StreamStats application, as discussed in the "Hydrologic Data" section. Each regulatory flow included flow-change locations, which are provided in table 2. The streamflows at each location were considered constant for the steady-state model.

\section{Model Sensitivity Analysis}

The primary model parameter manipulated during calibration was material properties ( $n$-value). To determine the sensitivity of the model to changes and uncertainties in material properties, the 1-percent AEP model with material properties set 10 percent higher and 10 percent lower than $n$-values used in the final calibration were run to quantify differences. The results from the 10-percent increase in material property $n$-values resulted in an average water-surface elevation change of -0.407 and a standard deviation of 0.135 . A 10-percent decrease in material property values resulted in changes in water-surface elevations of 0.431 and a standard deviation of 0.169 . The intent of the calibration process was to ensure that the material properties depicted in the model correspond to the target water-surface elevations. Although the roughness coefficients of the current (2020) model simulations match the target water elevations, the results of the sensitivity analysis indicate that small changes in material properties into the future, including land-cover or structure changes, can result in substantial changes in localized watersurface elevations.

\section{Development of Water-Surface Profiles and Map Products}

Water-surface profiles and map products were created for a reach of Joachim Creek within, and near, the city of De Soto. The water-surface profiles for the 10-, 4-, 2-, 1-, and 0.2-percent AEP flows generated by SRH-2D were postprocessed and exported from SMS (figs. 5-9). Maps of flood water-surface elevations, velocity, and water depth also were generated for the 1- and 0.2-percent AEP flows using output from the SRH-2D model that was processed and exported through SMS (figs. 10-15). The presented water-surface elevation maps of the 1- (fig. 10) and 0.2-percent (fig. 13) AEP flows also include the corresponding spatial extents of mainstem inundation from the Federal Emergency Management Agency (2019a) study for comparison. The results indicate the water-surface elevation profiles and inundation extents from products of this study are substantially lower than those of the published FIS (Federal Emergency Management Agency, 2019b). The differences can be attributed to the magnitude of estimated input flows and the hydraulic modeling technique. The Federal Emergency Management Agency (2019b) simulations were completed using input hydrographs and peak streamflows generated from a USACE Hydrologic Engineering Center Hydrologic Modeling System rainfallrunoff model and simulated in HEC-RAS (1D) using an unsteady flow method to account for overbank storage. The 


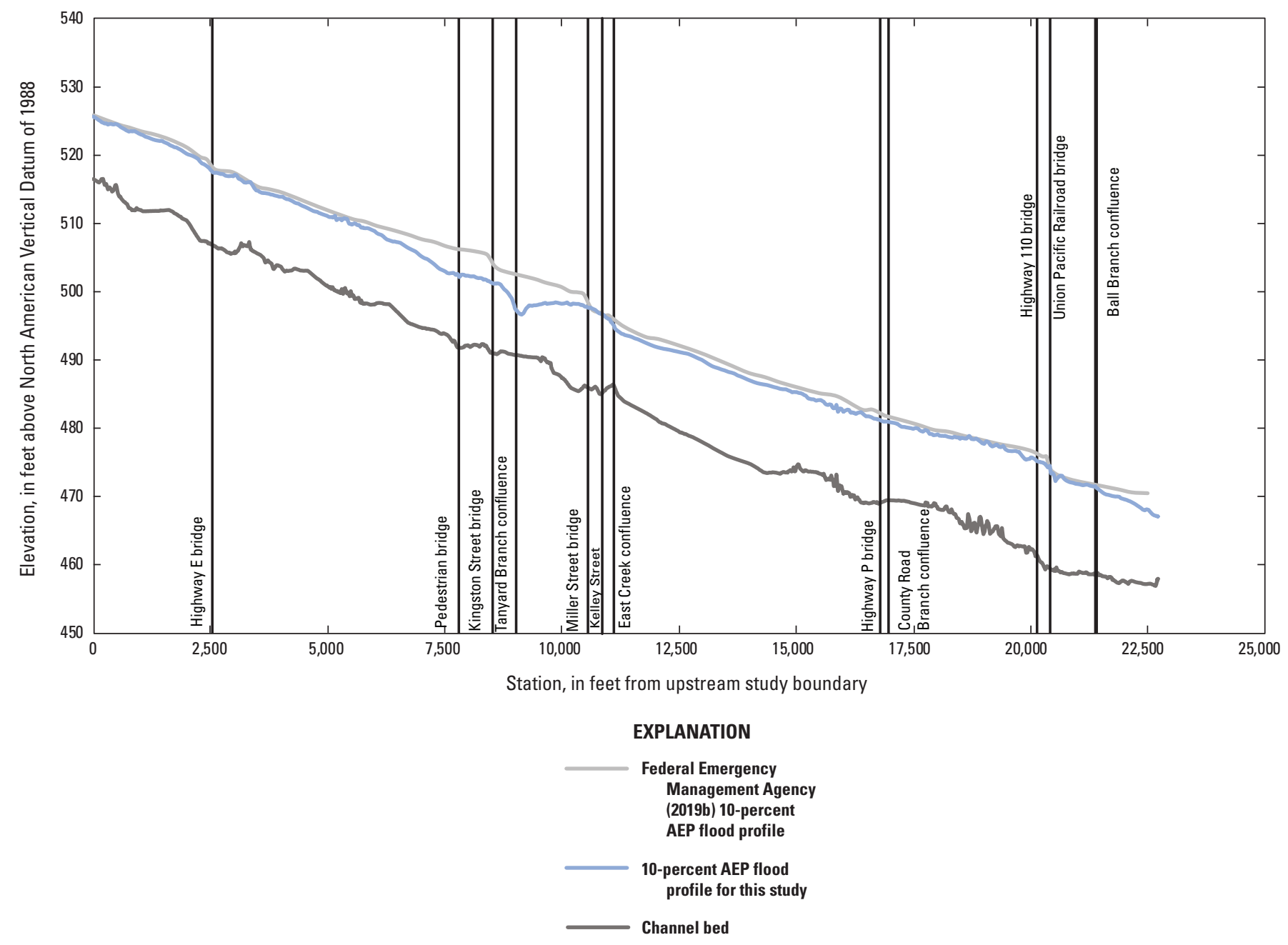

Figure 5. The 10-percent annual exceedance probability flood profile for the Joachim Creek study reach, De Soto, Missouri, from the Federal Emergency Management Agency (2019b) flood-insurance study and this study.

model input flows in this study (table 2) were generated from the USGS StreamStats utility and simulated with a steady-state two-dimensional model.

The DEM data used in developing the profiles and maps for this study were derived from the same lidar data described previously in the "Topographic and Bathymetric Data" section and, therefore, have an estimated vertical accuracy of $1 \mathrm{ft}$. Therefore, the resulting inundation maps have a vertical accuracy of about plus or minus $1.0 \mathrm{ft}$. Any inundated areas that were detached from the main channel were examined to identify subsurface connections with the main river, such as through culverts under roadways. Where such connections existed, the mapped inundated areas were retained in their respective flood maps; otherwise, the detached areas were erroneously delineated parts of the flood extent and were deleted. Bridges and structures are shown as inundated in the maps regardless of the relative level of the water surface to the structure. The flood-inundation areas were overlaid on high-resolution, georeferenced aerial photographs of the study area.

The generated profiles and map products from this study are subject to some uncertainty as a result of the modeling process. The probabilistic flows used to compute flood extents were estimated using regional regression equations within the USGS StreamStats application. These equations are based on historical observed data and are subject to uncertainty because additional peak-flow record, climate trends, and changes in land-cover conditions can affect results. A quantitative description of the uncertainty in StreamStats flow estimates is provided in the prediction intervals (table 4). Although simulated 


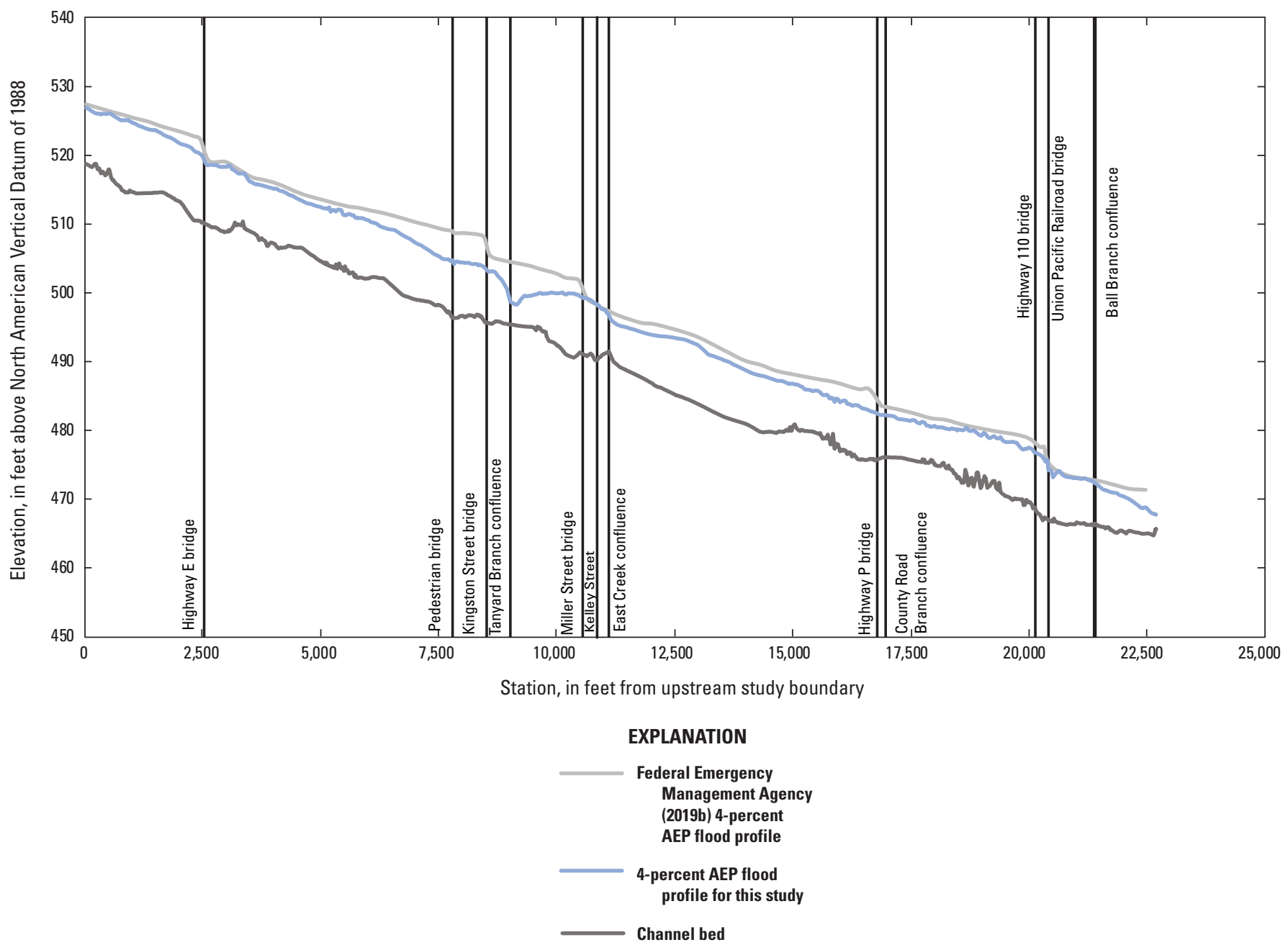

Figure 6. The 4-percent annual exceedance probability flood profile for the Joachim Creek study reach, De Soto, Missouri, from the Federal Emergency Management Agency (2019b) flood-insurance study and this study.

and observed water-surface elevations were within $0.5 \mathrm{ft}$, there is some uncertainty in the calibration from the lack of a fully developed stage-streamflow rating at the De Soto streamgage and the estimated overbank flow obtained from the previous 1D analysis (Heimann and others, 2019). Additionally, the input flows were modeled using steady-state hydraulic modeling that assumes steady, uniform, unobstructed flow. The land-cover characteristics and material properties in the model reflect land use as of 2016 (2016 National Land Cover Database; Jin and others, 2019) and hydraulic structures in the study area as of December 2020. Additional areas may be flooded as a result of unanticipated changes to streambed elevations or roughness, backwater into tributaries along the reach, or backwater from localized debris or ice jams. The accuracy of the floodwater extent portrayed on these maps also will vary with the accuracy of the DEM used to simulate the land surface.

The 1- and 0.2-percent AEP flows were modeled in a "no ceiling" condition to determine if pressure flow occurred at any bridge. The "no ceiling" condition simulated the watersurface elevation without the bridge deck/ceiling, and the simulated water-surface elevation is compared to the elevation of the lowest point in the bridge ceiling, or "low chord." If the modeled water-surface location is greater than the lowest ceiling elevation, then the bridge is modeled with pressure flow. Information from the 1- and 0.2-percent AEP profiles through the bridges in the study reach indicates that the 1-percent AEP flow did not result in pressure flow through any 


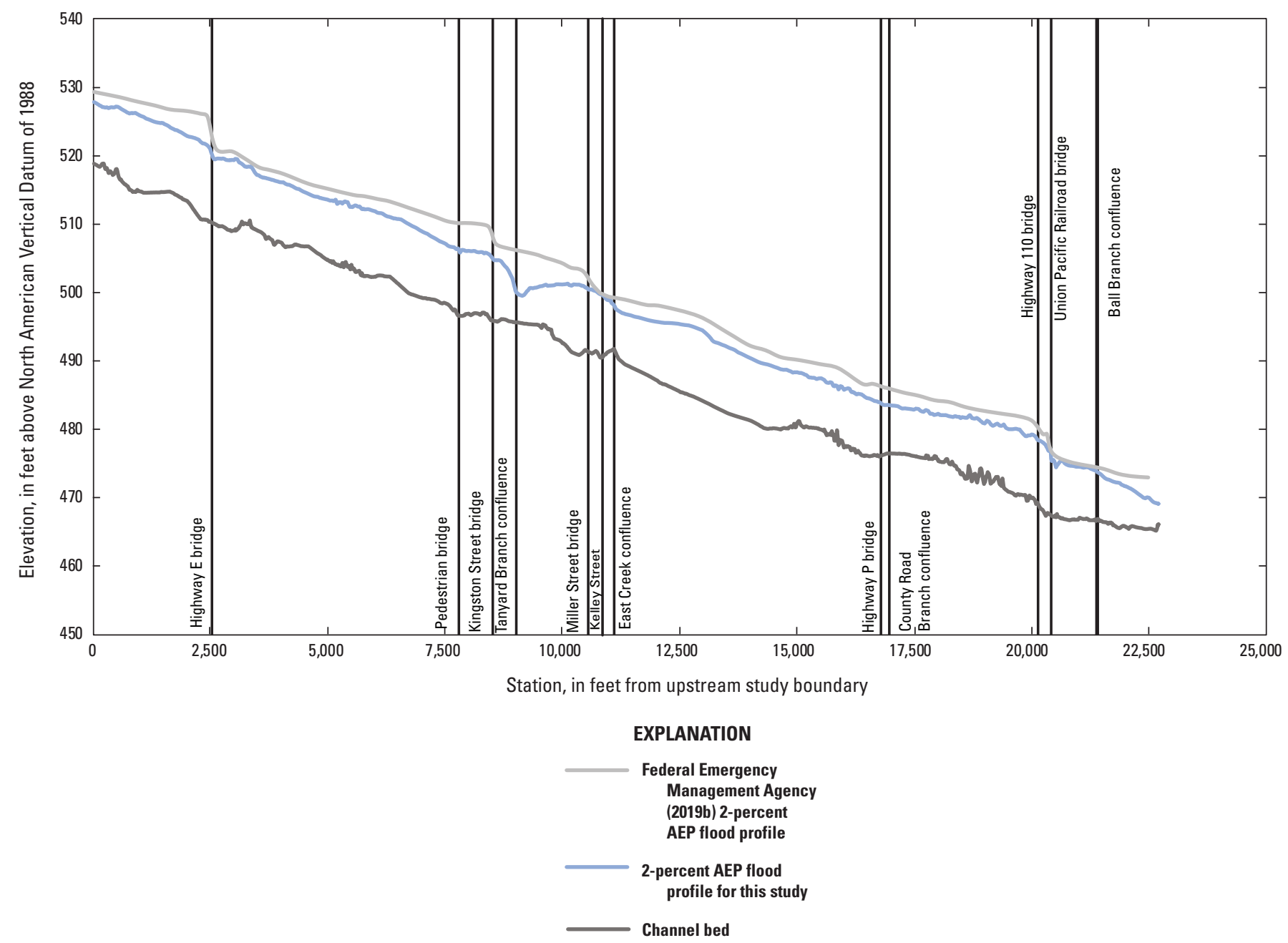

Figure 7. The 2-percent annual exceedance probability flood profile for the Joachim Creek study reach, De Soto, Missouri, from the Federal Emergency Management Agency (2019b) flood-insurance study and this study.

bridge. The 0.2-percent AEP flows resulted in pressure flow at five bridges (table 9): Pedestrian bridge, Kingston Street, Miller Street, Highway P, and Union Pacific Railroad bridges. The simulations of the water-surface elevation profiles of the 1- and 0.2-percent AEP floods indicate the elevation of the bridge crest was not exceeded at any bridge although the road approaches on either end of a bridge may be inundated (figs. 10, 13).

\section{Analysis of Water Depths at Selected Structures}

Water-surface elevations were determined at 231 selected structures within the city of De Soto that are within the Federal Emergency Management Agency (2019b) 1-percent floodplain area. The water-surface elevations for 1- and 0.2-percent AEP flows generated for this study and the associated water depths at these structures were quantified by comparing to adjacent grade elevations. Results indicate that for the 1-pecent AEP flow, 157 to 177 of the 231 structures were inundated, depending on whether the highest adjacent grade or lowest adjacent grade elevation was used for reference. Corresponding inundated depths at those affected structures were 0.02 to $7.11 \mathrm{ft}$ (appendix 1, table 1.1; table 10 in Hix and Heimann [2021; located in the "model_output" folder within the "Joachim_Creek_model.zip" file]). Using generated watersurface elevations from the 0.2-percent AEP flow simulation, 185 to 198 of the 231 structures were affected, depending on the selected grade elevation, and associated water depths were 0.12 to $9.28 \mathrm{ft}$. 


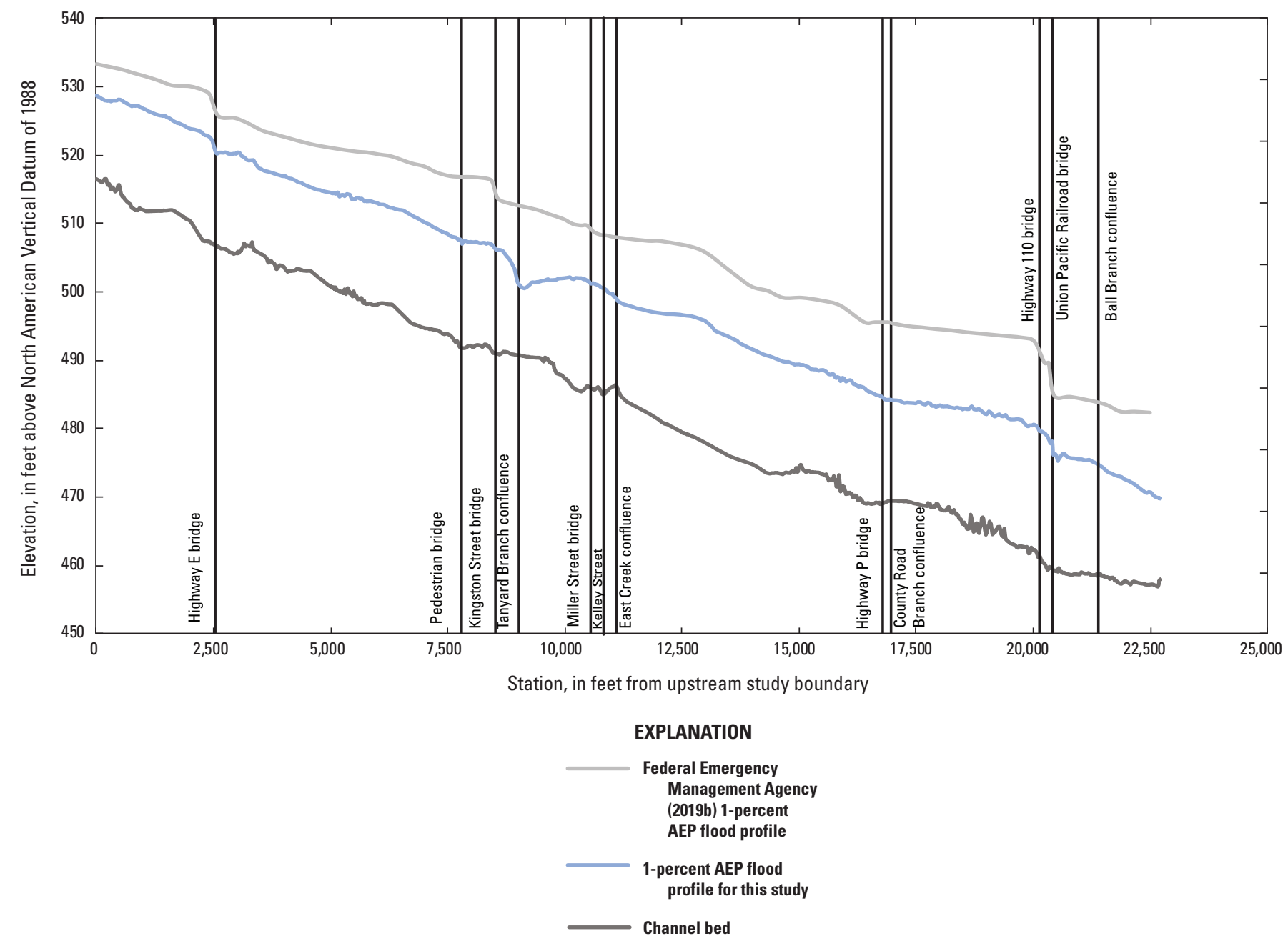

Figure 8. The 1-percent annual exceedance probability flood profile for the Joachim Creek study reach, De Soto, Missouri, from the Federal Emergency Management Agency (2019b) flood-insurance study and this study. 

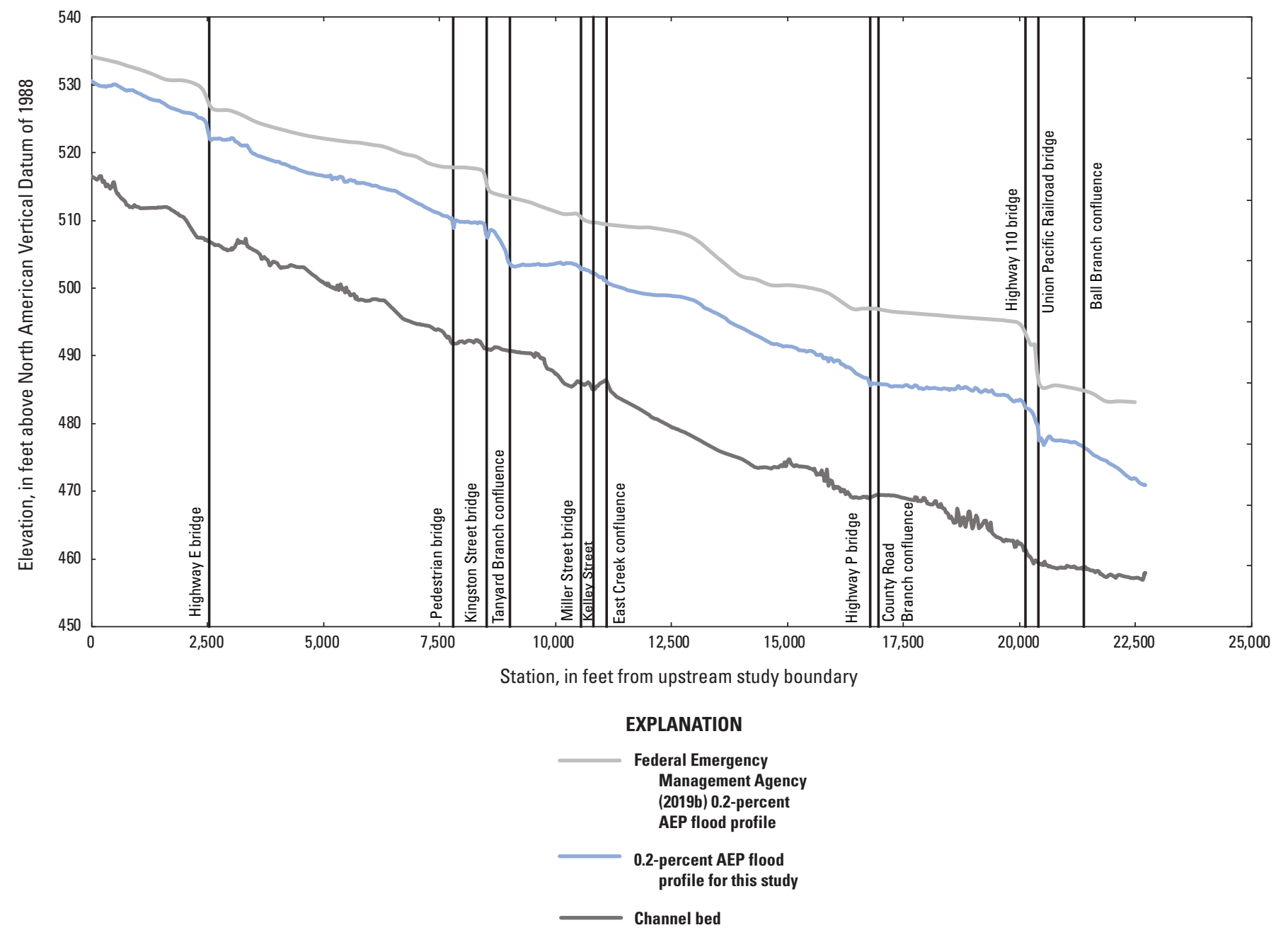

Figure 9. The 0.2-percent annual exceedance probability flood profile for the Joachim Creek study reach, De Soto, Missouri, from the Federal Emergency Management Agency (2019b) flood-insurance study and this study. 


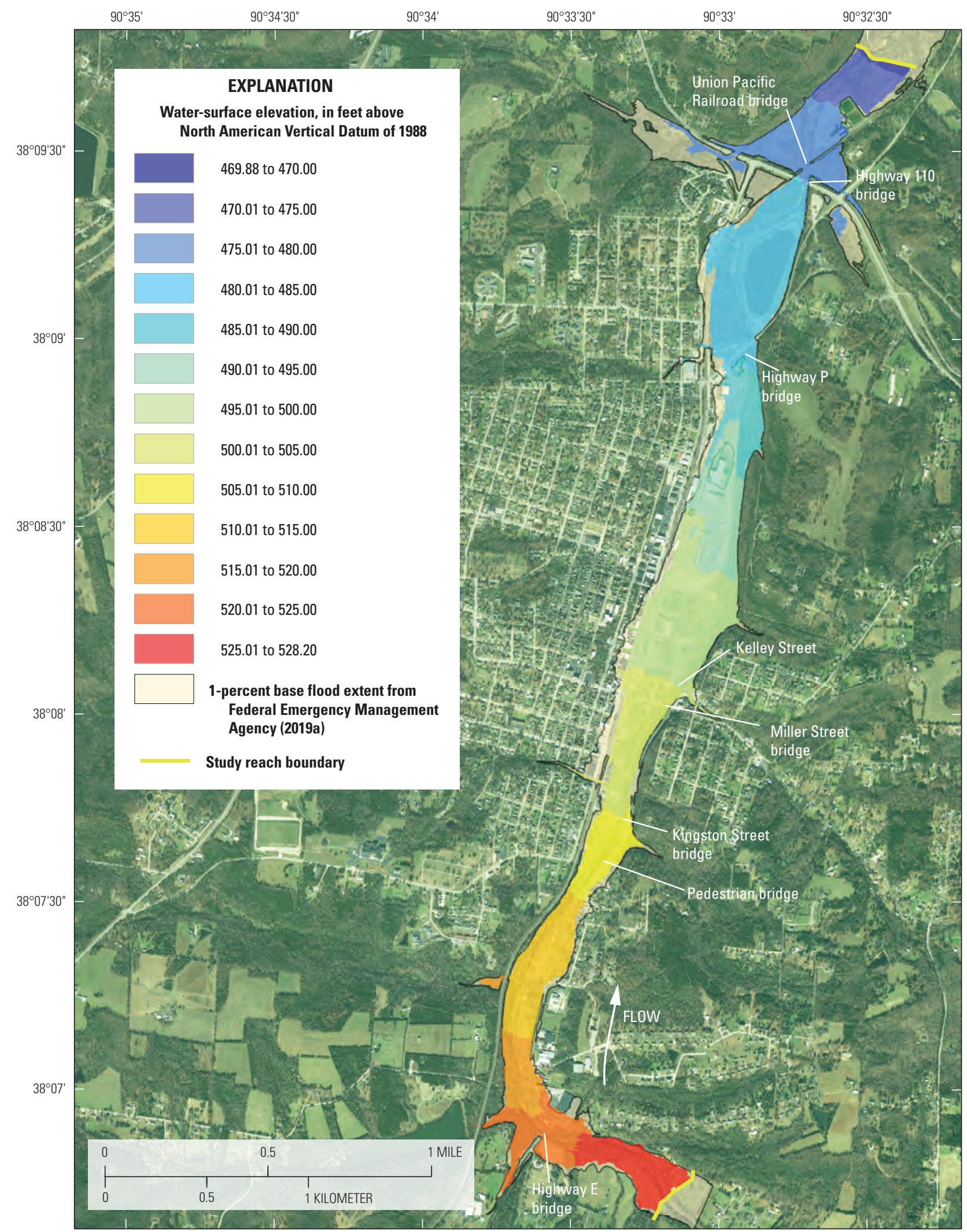

Base from Farm Service Agency, National Agricultural Imagery Program, 2018

Universal Transverse Mercator projection, zone 15 North

Horizontal coordinate information referenced to the North American Datum of 1983 (NAD 83)

Vertical elevations referenced to the North American Vertical Datum of 1988 (NAVD 88)

Figure 10. Modeled water-surface elevations for the 1-percent annual exceedance flow in the Joachim Creek study reach, De Soto, Missouri. 


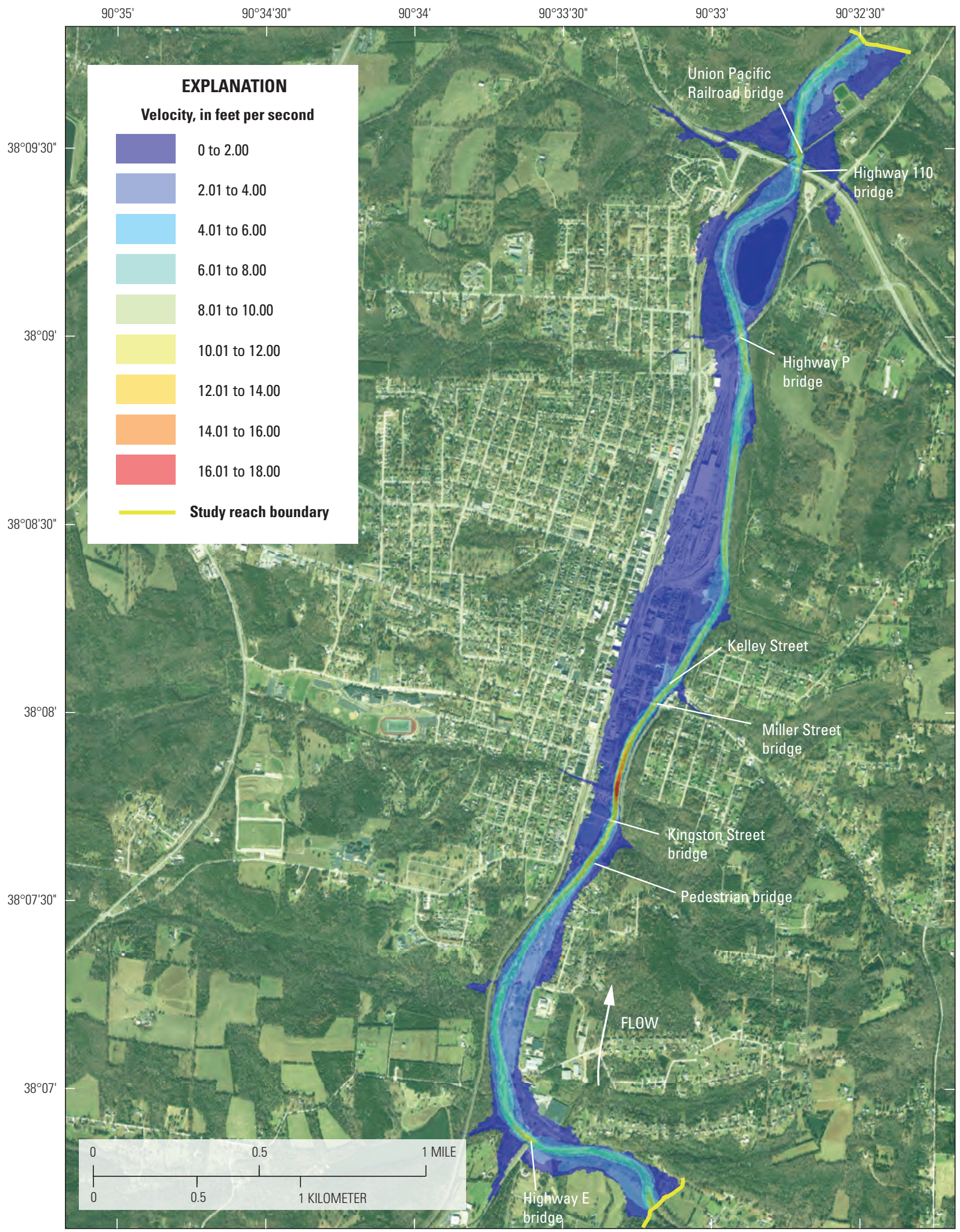

Base from Farm Service Agency, National Agricultural Imagery Program, 2018

Universal Transverse Mercator projection, zone 15 North

Horizontal coordinate information referenced to the North American Datum of 1983 (NAD 83)

Vertical elevations referenced to the North American Vertical Datum of 1988 (NAVD 88)

Figure 11. Modeled water velocities for the 1-percent annual exceedance flow in the Joachim Creek study reach, De Soto, Missouri. 


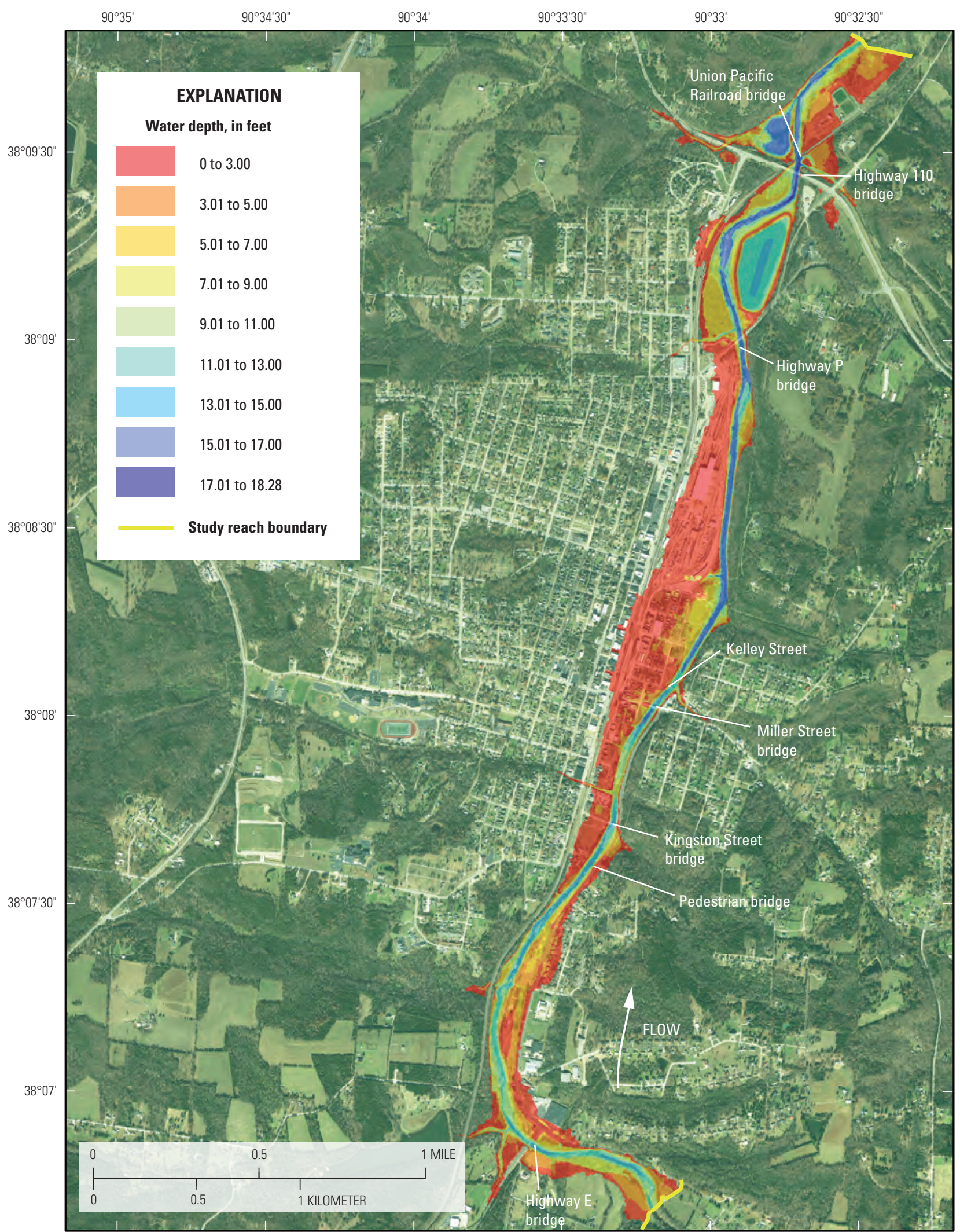

Base from Farm Service Agency, National Agricultural Imagery Program, 2018

Universal Transverse Mercator projection, zone 15 North

Horizontal coordinate information referenced to the North American Datum of 1983 (NAD 83)

Vertical elevations referenced to the North American Vertical Datum of 1988 (NAVD 88)

Figure 12. Modeled water depths for the 1-percent annual exceedance flow in the Joachim Creek study reach, De Soto, Missouri. 


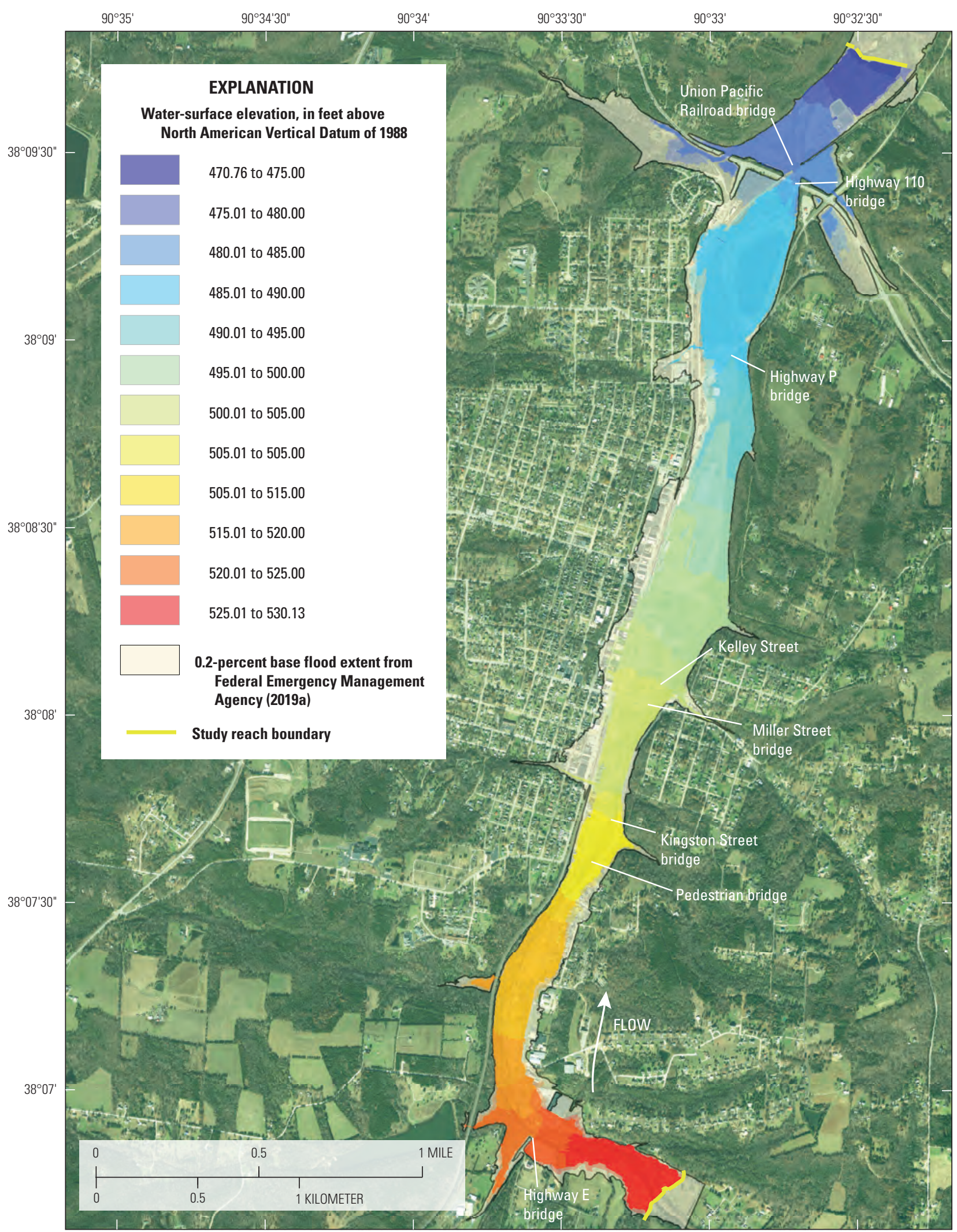

Base from Farm Service Agency, National Agricultural Imagery Program, 2018

Universal Transverse Mercator projection, zone 15 North

Horizontal coordinate information referenced to the North American Datum of 1983 (NAD 83)

Vertical elevations referenced to the North American Vertical Datum of 1988 (NAVD 88)

Figure 13. Modeled water-surface elevations for the 0.2-percent annual exceedance flow in the Joachim Creek study reach, De Soto, Missouri. 


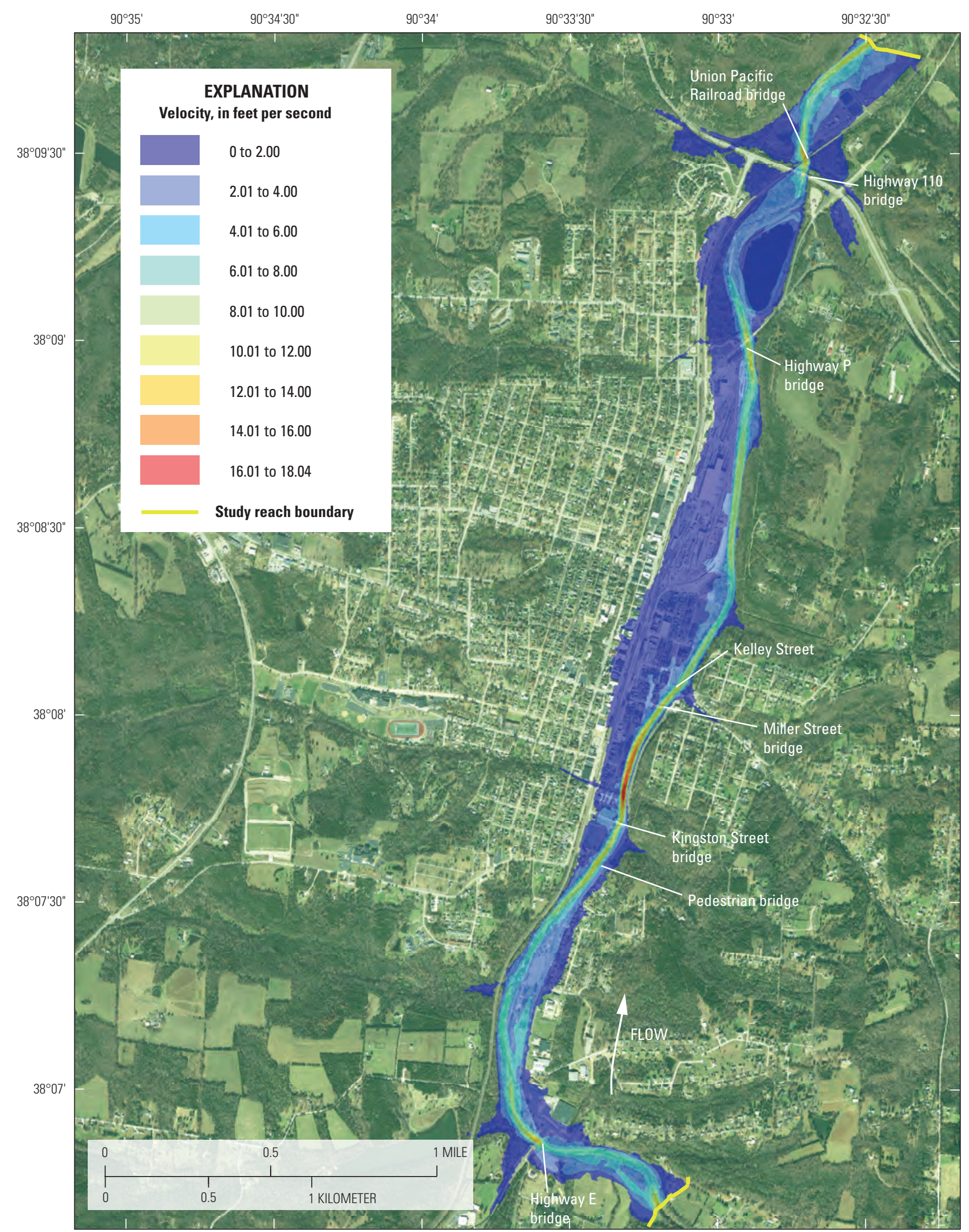

Base from Farm Service Agency, National Agricultural Imagery Program, 2018

Universal Transverse Mercator projection, zone 15 North

Horizontal coordinate information referenced to the North American Datum of 1983 (NAD 83)

Vertical elevations referenced to the North American Vertical Datum of 1988 (NAVD 88)

Figure 14. Modeled water velocities for the 0.2-percent annual exceedance flow in the Joachim Creek study reach, De Soto, Missouri. 


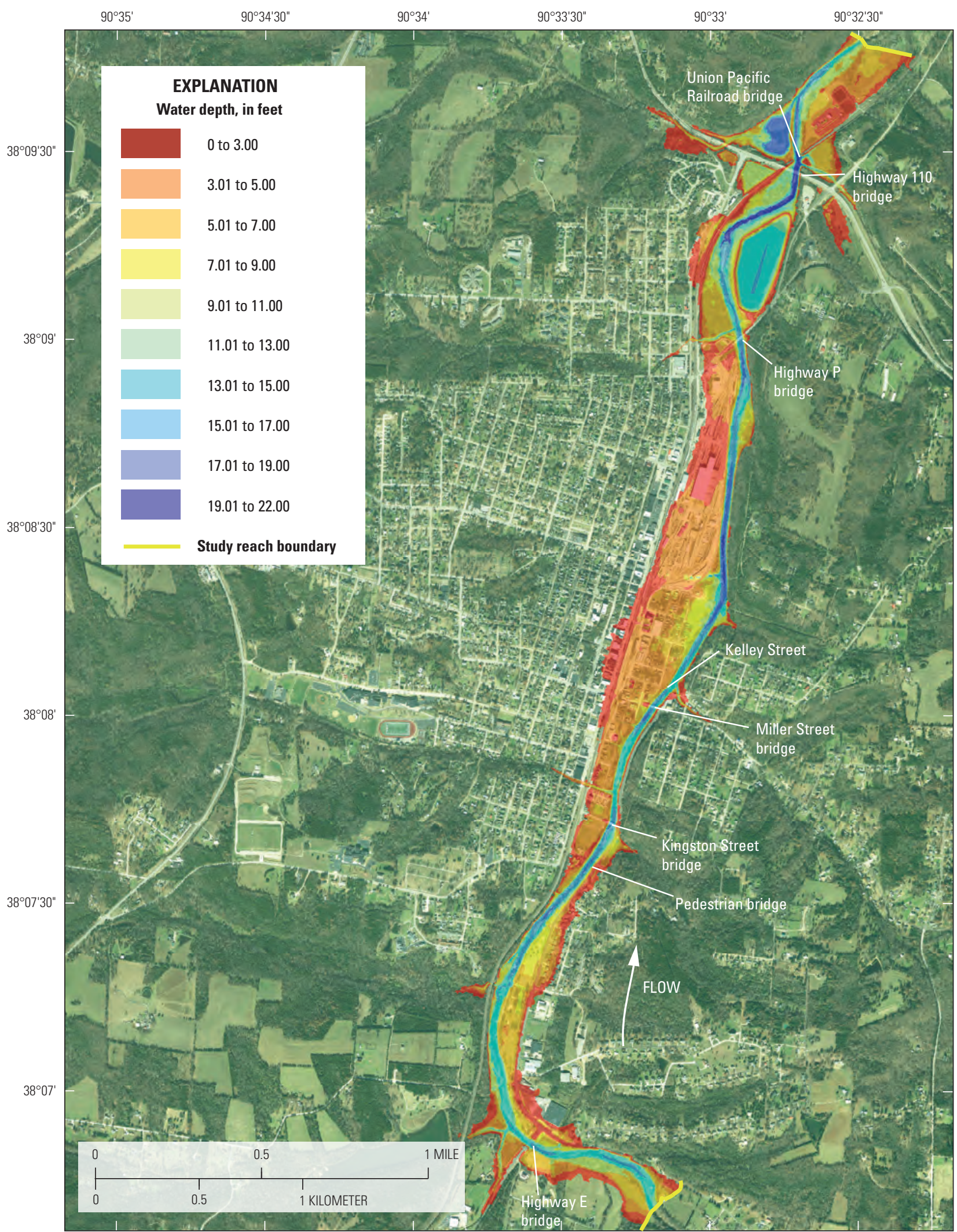

Base from Farm Service Agency, National Agricultural Imagery Program, 2018

Universal Transverse Mercator projection, zone 15 North

Horizontal coordinate information referenced to the North American Datum of 1983 (NAD 83)

Vertical elevations referenced to the North American Vertical Datum of 1988 (NAVD 88)

Figure 15. Modeled water depths for the 0.2-percent annual exceedance flow in the Joachim Creek study reach, De Soto, Missouri. 
[NAVD 88, North American Vertical Datum of 1988]

\begin{tabular}{|c|c|c|c|c|c|c|c|c|}
\hline \multirow{4}{*}{$\begin{array}{l}\text { Bridge } \\
\text { (fig. 1) }\end{array}$} & \multicolumn{4}{|c|}{ Water-surface elevation (feet above NAVD 88) } & \multirow{2}{*}{\multicolumn{2}{|c|}{$\begin{array}{c}\text { Pressure flow? (water-surface } \\
\text { elevation exceeded bridge ceiling/ } \\
\text { low chord?) }\end{array}$}} & \multirow{2}{*}{\multicolumn{2}{|c|}{$\begin{array}{l}\text { Water-surface elevation exceeded } \\
\text { bridge crest? }\end{array}$}} \\
\hline & \multirow{2}{*}{\multicolumn{2}{|c|}{$\begin{array}{c}\text { At upstream bridge face } \\
\text { Annual exceedance } \\
\text { probability }\end{array}$}} & \multirow{3}{*}{$\begin{array}{c}\text { Structure } \\
\text { elevation at } \\
\text { lowest point in } \\
\text { bridge ceiling or } \\
\text { low chord }\end{array}$} & \multirow{3}{*}{$\begin{array}{l}\text { Structure elevation } \\
\text { at bridge crest } \\
\text { (highest point of } \\
\text { bridge deck) }\end{array}$} & & & & \\
\hline & & & & & \multicolumn{4}{|c|}{ Annual exceedance probability } \\
\hline & 0.2 percent & 1 percent & & & 0.2 percent & 1 percent & 0.2 percent & 1 percent \\
\hline Highway E & 523.05 & 521.10 & 523.75 & 529.90 & NO & NO & NO & NO \\
\hline Pedestrian & 509.40 & 507.51 & 508.40 & 510.40 & YES & NO & NO & NO \\
\hline Kingston Street & 508.06 & 506.46 & 506.78 & 511.58 & YES & NO & NO & NO \\
\hline Miller Street & 503.00 & 501.40 & 502.90 & 509.20 & YES & NO & NO & NO \\
\hline Highway P & 486.64 & 484.76 & 485.60 & 493.30 & YES & $\mathrm{NO}$ & NO & NO \\
\hline Highway 110 & 482.75 & 480.01 & 505.65 & 515.40 & NO & NO & NO & NO \\
\hline Union Pacific Railroad & 479.48 & 477.52 & 478.50 & 487.50 & YES & $\mathrm{NO}$ & NO & $\mathrm{NO}$ \\
\hline
\end{tabular}




\section{Summary}

Water-surface profiles and map products were developed for selected regulatory flows for a 6.7-mile reach of Joachim Creek, De Soto, Missouri. The flood products were developed using a two-dimensional model and pre- and postprocessing software to compute water-surface elevation profiles and to generate maps of inundation area, depth, and velocities. The hydraulic model was calibrated using global positioning system measurements of water-surface elevations of highwater marks from the April 18, 2013, flood and the maximum measured streamflow measured on September 8, 2018, at the U.S. Geological Survey streamgage Joachim Creek at De Soto, Mo. (station 07019500).

The probabilistic peak streamflows used in this study for input in the hydraulic model were determined using the U.S. Geological Survey StreamStats application. The magnitude of the basin yield of input streamflows generated from StreamStats estimates within the study reach was verified with yields from at-site flood-frequency analyses at long-term stations within the same hydrologic region. Comparisons indicate that the StreamStats utility using regional regression analyses through 2012 (and updated through 2019 at selected locations) provides a conservatively high estimate of peak streamflows and basin yields compared to nearby station-derived floodfrequency estimates using long-term peak-flow record.

The calibrated model was used to compute water-surface profiles for the 10-, 4-, 2-, 1-, and 0.2-percent annual exceedance probability flows and maps of flood-inundation extent, velocities, and water depths for the 1- and 0.2-percent annual exceedance probability flows. The probabilistic flows correspond to a range of stages at the reference streamgage from 10.57 to 17.53 feet (ft). These stages correspond to elevations of $502.47 \mathrm{ft}$ and $509.43 \mathrm{ft}$ above the North American Vertical Datum of 1988, respectively. Water-surface elevations and inundation extents of generated profiles and maps were substantially lower than similar products produced for the 2019 flood-insurance study. Differences in water-surface elevations between profiles and maps in this study and a 2019 flood-insurance study can be attributed to differences in input streamflows and hydraulic simulation techniques.

Simulated water-surface elevations for the 1- and 0.2-percent annual exceedance probability floods were compared to adjacent grade elevations at 231 structures within the city of De Soto. From 157 to 177 structures were affected at the 1-percent annual exceedance flow, depending on whether the lowest adjacent grade or highest adjacent grade was used for comparison, and 185 to 198 structures were affected at the 0.2-percent annual exceedance probability flow. Inundation depths at affected structures were 0.02 to $7.11 \mathrm{ft}$ at the 1-percent annual exceedance probability flow and 0.12 to $9.28 \mathrm{ft}$ at the 0.2 -percent annual exceedance probability flow. The results of this study can provide additional information to managers, engineers, and planners to use in decision making regarding floodplain management, flood risk, and mitigation efforts from flooding along Joachim Creek.

\section{References Cited}

American Society for Photogrammetry and Remote Sensing, 1990, ASPRS accuracy standards for large-scale maps: American Society for Photogrammetry and Remote Sensing, 3 p., accessed December 17, 2019, at http://www. asprs.org/a/society/committees/standards/1990_jul_10681070.pdf.

American Society for Photogrammetry and Remote Sensing, 2004, ASPRS guidelines-Vertical accuracy reporting for lidar data: American Society for Photogrammetry and Remote Sensing, 20 p., accessed December 17, 2019, at https://www.asprs.org/a/society/committees/standards/ Vertical_Accuracy_Reporting_for_Lidar_Data.pdf.

Aquaveo, 2020, SMS 13.1-The complete surface-water solution: Aquaveo web page, accessed February 2020 at https://www.aquaveo.com/software/sms-surface-watermodeling-system-introduction.

Arcement, G.J., and Schneider, V.R., 1989, Guide for selecting Manning's roughness coefficients for natural channels and flood plains: U.S. Geological Survey Water-Supply Paper 2339, 38 p. [Also available at https://doi.org/10.3133/ wsp2339.]

Bureau of Reclamation, 2008, SRH-2D version 2Theory and user's manual: Denver, Colorado, Bureau of Reclamation, 97 p., accessed November 2015 at h ttps://www.usbr.gov/tsc/techreferences/computer $\% 20$ software/models/srh2d/downloads/Manual-SRH2D-v2.0Nov2008.pdf.

Chow, V.T., 1959, Open-channel hydraulics: New York, McGraw-Hill, 680 p.

Collier, J.E., 1955, Geographic regions of Missouri: Annals of the Association of American Geographers, v. 45, no. 4, p. 368-388. [Also available at https://doi.org/10.1111/ j.1467-8306.1955.tb01493.x.]

England, J.F., Jr., Cohn, T.A., Faber, B.A., Stedinger, J.R., Thomas, W.O., Jr., Veilleux, A.G., Kiang, J.E., and Mason, R.R., Jr., 2018, Guidelines for determining flood flow frequency_Bulletin 17C (ver. 1.1, May 2019): U.S. Geological Survey Techniques and Methods, book 4, chap. B5, 148 p. [Also available at https://doi.org/ 10.3133/tm4B5.]

Federal Emergency Management Agency, 1981, Flood Insurance Study, city of De Soto, Jefferson County, Missouri: Washington, D.C., Federal Emergency Management Agency. 
Federal Emergency Management Agency, 2002, Flood Insurance Study, city of De Soto, Jefferson County, Missouri: Washington, D.C., Federal Emergency Management Agency.

Federal Emergency Management Agency, 2006, Flood Insurance Study, Jefferson County, Missouri, and incorporated areas-Volume 1: Washington, D.C., Federal Emergency Management Agency, 63 p.

Federal Emergency Management Agency, 2019a, FEMA flood map service center: Federal Emergency Management Agency web page, accessed October 16, 2020, at https://msc.fema.gov/portal/home.

Federal Emergency Management Agency, 2019b, Flood Insurance Study, Jefferson County, Missouri, and incorporated areas-Volume 1: Washington, D.C., Federal Emergency Management Agency, 104 p.

Fenneman, N.M., 1938, Physiography of eastern United States: New York, McGraw-Hill Book Co., Inc., 689 p.

Flynn, K.M., Kirby, W.H., and Hummel, P.R., 2006, User's manual for program PeakFQ-Annual flood-frequency analysis using Bulletin 17B guidelines: U.S. Geological Survey Techniques and Methods, book 4, chap. B4, 42 p. [Also available at https://doi.org/10.3133/tm4B4.]

Heidemann, H.K., 2018, Lidar base specification (ver. 1.3, February 2018): U.S. Geological Survey Techniques and Methods, book 11, chap. B4, 101 p., accessed May 2020 at https://doi.org/10.3133/tm11b4.

Heimann, D.C., and Hix, K.D., 2021, PeakFQ software input files and selected output files for selected long-term streamgages near Jefferson County, Missouri, through water year 2019: U.S. Geological Survey data release, https://doi. org/10.5066/P9ACXXI7.

Heimann, D.C., Holmes, R.R., Jr., and Harris, T.E., 2018, Flooding in the southern Midwestern United States, AprilMay 2017: U.S. Geological Survey Open-File Report 2018-1004, 36 p., accessed October 2020 at https://doi.org/ 10.3133/ofr20181004.

Heimann, D.C., Voss, J.D., and Rydlund, P.H., Jr., 2019, Flood-inundation maps for Joachim Creek, De Soto, Missouri, 2018: U.S. Geological Survey Scientific Investigations Report 2019-5068, 10 p., accessed May 2020 at https://doi.org/10.3133/sir20195068.

Hix, K.D., and Heimann, D.C., 2021, Geospatial data and model archive associated with the twodimensional hydraulic analysis of Joachim Creek, De Soto, Missouri: U.S. Geological Survey data release, https://doi.org/10.5066/P92MQYE7.
Holmes, R.R., Jr., Koenig, T.A., Rydlund, P.H., Jr., and Heimann, D.C., 2016, Examination of flood characteristics at selected streamgages in the Meramec River Basin, eastern Missouri, December 2015-January 2016: U.S. Geological Survey Open-File Report 2016-1140, 7 p., accessed October 2020 at https://doi.org/10.3133/ofr20161140.

Jin, S., Homer, C., Yang, L., Danielson, P., Dewitz, J., Li, C., Zhu, Z., Xian, G., and Howard, D., 2019, Overall methodology design for the United States National Land Cover Database 2016 products: Remote Sensing, v. 11, no. 24, art. 2971, 32 p. [Also available at https://doi.org/10.3390/ rs11242971.]

Missouri Spatial Data Information Service, 2019a, Missouri lidar DEM download tool: Missouri Spatial Data Information Service digital data, accessed June 5, 2019, at https://msdis.maps.arcgis.com/apps/View/index.html? appid=350bcb69dfb74ca58aae74a32728f58b.

Missouri Spatial Data Information Service, 2019b, Missouri NAIP data: Missouri Spatial Data Information Service web page, accessed June 5, 2019, at https://msdis-archive.mis souri.edu/archive/Missouri_Imagery/naip2018/.

Rydlund, P.H., Jr., and Densmore, B.K., 2012, Methods of practice and guidelines for using survey-grade Global Navigation Satellite Systems (GNSS) to establish vertical datum in the United States Geological Survey: U.S. Geological Survey Techniques and Methods, book 11, chap. D1, 102 p. with appendixes. [Also available at https://doi.org/10.3133/tm11D1.]

Southard, R.E., and Veilleux, A.G., 2014, Methods for estimating annual exceedance-probability discharges and largest recorded floods for unregulated streams in rural Missouri: U.S. Geological Survey Scientific Investigations Report 2014-5165, 39 p. [Also available at https://doi.org/10.3133/ sir20145165.]

Turnipseed, D.P., and Sauer, V.B., 2010, Discharge measurements at gaging stations: U.S. Geological Survey Techniques and Methods, book 3, chap. A8, 87 p. [Also available at https://doi.org/10.3133/tm3A8.]

U.S. Army Corps of Engineers, 2019, Upper Joachim Creek Floodplain Management Plan for the City of De Soto and Jefferson County, Missouri: Upper Joachim Creek Floodplain Management Planning Partners, 71 p. with appendixes, accessed December 2019 at https://www .mvs.usace.army.mil/Portals/54/docs/pm/Upper\%20Joachi m\%20Creek/Draft\%20Upper\%20Joachim\%20Creek \%20FMP\%20-\%206\%20June\%202019.pdf.

U.S. Geological Survey, 2020a, StreamStats, version 4.40, Missouri: U.S. Geological Survey web application, accessed June 2020 at https://streamstats.usgs.gov/ss/. 
U.S. Geological Survey, 2020b, USGS 07019500, Joachim Creek at De Soto, Missouri, in USGS water data for the Nation: U.S. Geological Survey National Water Information System database, accessed May 2020 at https://doi.org/ 10.5066/F7P55KJN. [Site information directly accessible at https://waterdata.usgs.gov/nwis/inventory/?site_no= 07019500\&agency_cd=USGS\&amp.]

U.S. Geological Survey, 2020c, USGS water data for the Nation: U.S. Geological Survey National Water Information System database, accessed May 2020 at https://doi.org/10.5066/F7P55KJN. 


\section{Appendix 1}

Table 1.1. Summary of water-surface elevations and depths at selected structures in city of De Soto, Missouri, for 1- and 0.2-percent annual exceedance probability streamflows. [Available for download at https://doi.org/10.3133/sir20215058] 
For more information about this publication, contact: Director, USGS Central Midwest Water Science Center 1400 Independence Road

Rolla, M0 65401

573-308-3667

For additional information, visit: https://www.usgs.gov/ centers/cm-water

Publishing support provided by the

Rolla Publishing Service Center 


\section{$\frac{\mathbb{2}}{3}$}

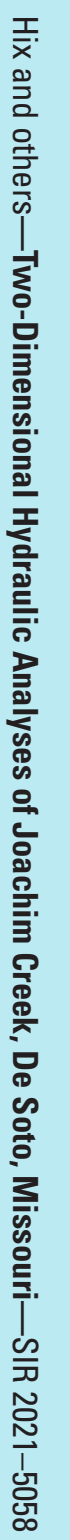

